\title{
Capitalismo del fin de los tiempos: actualidad de la simbiosis entre violencia y acumulación originaria
}

\section{Humberto Márquez Covarrubias*}

Resumen. Distante de un proceso civilizatorio donde florezcan la libertad, el progreso, la democracia y el bien común, el sistema capitalista mundial avanza de manera incesante por formas de acumulación soportado por la violencia. Desde sus orígenes, la acumulación de capital representa una forma violenta de enriquecimiento que hace posible el despliegue y futuro del capitalismo en formas de acumulación ampliada. Esta acumulación originaria aparece, no obstante, como un rasgo continuo o permanente a lo largo del desarrollo del capitalismo. Desde la época colonial, pasando por el imperialismo hasta el capitalismo actual marcado por la decadencia del sistema y la crisis civilizatoria de amplio espectro. Ante la tendencia inexorable del decrecimiento de la tasa de ganancia por el incremento del capital constante y el declive de la plusvalía, la tasa de ganancia, la recurrencia de violencia acontece en el plano económica, político y cultural, es el hecho más constante, y aparece en las periferias del sistema mundial pero también en las periferias alojadas en los centros como requisito para la reproducción incesante del sistema capitalista.

Palabras clave: capitalismo, violencia, acumulación originaria, explotación, Estado.

* Docente investigador de la Unidad Académica de Estudios del Desarrollo de la Universidad Autónoma de Zacatecas. 


\section{End-stage Capitalism:}

The State of Symbiosis between Violence and Original Accumulation

Abstract. Far from a civilizing process where freedom, progress, democracy and the common good flourishes, the world capitalist system marches incessantly onward through processes of accumulation underpinned by violence. From its inception, the accumulation of capital represented a violent method of enrichment that fosters its spread and leads to a future of capitalism with ever-broader pathways to accumulation. This original accumulation appears, moreover, as an ever-present or permanent characteristic throughout the development of capitalism: from the colonial era, through imperialism, to today's capitalism marked by the decadence of the system and a broad-spectrum civilizing crisis. Given the inexorable downward trend in the rate of profit per increment of constant capital and the decline in capital gains, the rate of profit, the persistence of violence occurring in the economic, political and cultural spheres, is a constant reality, appearing in the periphery of the world system but also in the peripheries of the cores as a necessary component of the unending reproduction of the capitalist system.

Keywords: capitalism, violence, original accumulation, exploitation, State. 


\section{Genealogía de la violencia}

Los métodos violentos aplicados a «sangre y lodo» (Marx, 1982a:950) para expropiar los medios de producción y convertir la fuerza de trabajo en mercancía, con objeto de engendrar el capitalismo en Inglaterra entre los siglos XV y XIX y en las colonias británicas en el siglo XIX, son desmenuzados bajo el concepto de acumulación originaria, el cierre magistral de $E l$ capital de Karl Marx.

En términos históricos, el capitalismo es engendrado por una violencia originaria. Sin embargo, este proceso no es un dato fundacional, es una constante a lo largo del desarrollo del capitalismo, por lo que la acumulación se basa en una violencia originaria y permanente, una contradicción de los términos que califican la esencia violenta del capitalismo, como un oxímoron. El nexo íntimo del capitalismo con la violencia es una constante y un motor propulsor de la expansión del capital, que se ensaña más en las periferias del mundo. La violencia se ejerce sobre las clases subalternas, pero también sobre la naturaleza con objeto de ampliar de modo incesante los espacios económicos de valorización.

La violencia es una fuerza estructural del desarrollo del capitalismo. No cesa de ejercerla sobre su entorno social y ambiental. En apariencia, el proceso de valorización de valor sigue pautas no violentas, inmerso en un proceso civilizatorio enmarcado en un mundo de libertades, democracia y progreso, pero en realidad la explotación del trabajo asalariado por el capital es una violencia económica cotidiana. El capital no observa límite alguno para la explotación laboral: la duración e intensidad de la jornada laboral y el salario son negociados socialmente, sin observar principios morales o pleitesías humanistas. Esta es la arena de la guerra social, que se 
libra cotidianamente y engendra la violencia entre las clases sociales. Si pudiera, el capital habría destruido a los trabajadores; no lo ha hecho porque siguen siendo necesarios.

En la economía capitalista pervive una violencia inmanente que se ejerce sobre la corporalidad viviente cuando las personas son transformadas en mercancías humanas, es decir, esclavizadas, sometidas a la servidumbre y al despotismo patronal. Además, se anida una violencia contra la naturaleza, cuando se convierte en recursos naturales, meros insumos productivos, que se consumen aceleradamente en la industria y se desechan como basura, deyecciones, flujos contaminantes. Así pues, la acumulación capitalista se funda en la violencia originaria y transcurre como un dispositivo permanente tanto en la relación imperio-colonia o centro-periferia como en la relación capital-trabajo.

La cuestión de la violencia aparece planteada como un asunto congénito al capitalismo. En el libro primero de El capital, el problema se estudia desde dos conceptos fundamentales: el plusvalor y la acumulación originaria de capital. La relación simbiótica entre capitalismo y violencia es analizada a partir de dos formas generales: la explotación del trabajo asalariado, una explotación económica intrínseca a la relación capital-trabajo propia de la gran industria y la acumulación originaria y el sistema colonial, la violencia por el despojo y saqueo que separan al productor directo de sus medios de producción y lo obligan a la proletarización, lo cual permite la capitalización naciente y la formación de las clases fundamentales de la sociedad burguesa y la expansión mundial del capitalismo bajo formas de dominación colonial. De una parte, se trata de la violencia de la acumulación originaria que Marx denomina violencia directa, el despojo, la matanza, el sistema colonial y la sobreexplotación; de otra parte, nos remite a 
la violencia encubierta de la apropiación del trabajo no retribuido. En uno y otro caso, el capitalismo despliega una violencia que en un caso es más que evidente por su brutalidad y en otra aparece de forma mistificada en lo estructural. «La violencia es la partera de toda sociedad vieja preñada de una nueva. Ella misma es una potencia económica» (Marx, 1982a:940). En tanto potencia alumbra e instaura al capitalismo, pero de igual manera lo acompaña en su desarrollo industrial y en su despliegue por el mercado mundial.

\section{Hambre insaciable}

El misterio del capital descansa en una relación de poder asimétrico entre capital y trabajo. Bajo la forma de ganancia subyace un mecanismo invisible que da forma a la plusvalía. La categoría de plusvalía devela una radical relación de inequidad sobre la que se despliega la sociedad capitalista y hace estallar el aparente intercambio de equivalencias, trabajo por salario. En lugar de un intercambio equilibrado, igualitario y armónico, la forma transfigurada de la ganancia que sustrae el empresario, resulta de la violencia del trabajo no retribuido.

En la experiencia inmediata, la jornada de trabajo se nos presenta como un proceso homogéneo y continuo, acaso con algunos problemas; sin embargo, es intrínsecamente contradictoria. En su configuración acontecen dos momentos: en la primera parte el trabajador reproduce un valor equivalente al salario (trabajo necesario) y en la segunda parte correlativos crea un valor excedente, el plusvalor, mediante el cual el empresario no abona equivalente alguno (plustrabajo). 
La relación capital-trabajo, en apariencia, es equitativa al estar mediada por el salario que fijaría una relación de igualdad entre trabajador y capitalista. Aunque dicha ficción igualitaria encubre la violencia inherente a la relación capital-trabajo. Dentro del capitalismo, la fuerza de trabajo es una mercancía, y como tal está sujeta a la compraventa. Empero, no es una mercancía cualquiera, sino una mercancía singular, pues dispone de la capacidad extraordinaria de procrear valor y además de engendrar más valor que el que ella misma contiene. Como ocurre con toda mercancía, el valor de cambio de la fuerza de trabajo, expresado por el salario, se determina por el costo de su producción, es decir, el valor de los medios de subsistencia indispensables para el obrero determina el valor de la fuerza de trabajo (Marx, 1987a); mientras que el trabajo coincide con la subjetividad viva, el trabajo vivo. En tanto sólo existe como actitud del ser viviente, el costo de producción del trabajador está determinado por la cantidad de dinero equivalente a la suma de medios de vida necesarios que le permitan asegurar su subsistencia; ello simplemente para que al día siguiente el trabajador pueda presentarse a trabajar y poner en acción su energía creadora (Marx, 1849).

Como Marx lo demostrara, el valor de la fuerza de trabajo retribuido por el capital mediante el salario no coincide con el ejercicio de esa fuerza, si así fuese estaríamos ante una relación de igualdad entre el costo de la fuerza de trabajo y lo que ésta produce, en consecuencia, el capital no se apropiaría de nada, no extraería la ganancia. La diferencia entre el costo de la fuerza de trabajo y lo producido por dicha fuerza es el punto crítico del capital. El trabajador produce más allá del tiempo necesario con el fin de reponer el salario y ese trabajo gratuito, el plustrabajo, es la fuente de la ganancia. De hecho, el capital se funda y perpetúa sobre la distancia creciente entre el 
salario y lo producido por el trabajador. En esa medida, el concepto plusvalía entraña la esencia de la violencia y el conflicto propio del capital.

La moderna sociedad capitalista se sustenta en la relación capital-trabajo que se orienta por una violencia profunda, silenciosa, muda, una violencia estructural, constitutiva. El capital se erige sobre «la apropiación violenta del poder creador del obrero» (Nicolaus, 2007:XXX), es «El robo del tiempo de trabajo ajeno, sobre el cual se funda la riqueza actual» (Marx, 2006:228).

Para Marx (1988a:282), el capital tiene un hambre insaciable de plustrabajo. El devenir del capitalismo moderno tiene su piedra de toque en el poder totalizador del capital cuya urgencia compulsiva por apropiarse del trabajo suplementario, impulsa el desarrollo de las fuerzas productivas. Los métodos de organización del trabajo y la tecnología empleada en la producción sufren continuas metamorfosis en pos del imperativo del plusvalor, que le confieren al capitalismo un carácter revolucionario, pero igualmente violento y depredador. Progreso y barbarie son las dos caras de una misma moneda. La subsunción del trabajo y la tecnología al capital responden al puro interés de succionar el trabajo excedente, acordes a la racionalidad del plusvalor, que desata fuerzas violentas, flexibles y opresoras contra los trabajadores, reducidos a meros apéndices de la máquina, el «monstruo animado» (Marx, 1988a:236) que absorbe plustrabajo, y el capital aparece como una cosa, un valor henchido de valor.

El descubrimiento del plusvalor devela los mecanismos económico y político de la violencia subyacente en la moderna sociedad capitalista. Los sujetos son subsumidos por el capitalismo bajo las premisas del plusvalor y para ello se despliega una violencia expropiatoria en la esfera productiva, en la cotidianidad de las relaciones económicas, donde el trabajador asalariado aparece como un «esclavo moderno». 


\section{Fuerza productiva de la violencia}

Una vez develada la lógica del plusvalor que determina el desarrollo del capitalismo, en el capítulo XXIV de El capital, Marx examina la génesis del modo de producción capitalista. La estructura social del capitalismo se basa en dos clases sociales antagónicas, los propietarios de los medios de producción y los desposeídos que para vivir deben vender lo único que tienen, su propia fuerza de trabajo, su corporalidad viviente. El presupuesto del capitalismo es la existencia de una clase desposeída que tiene que venderse como mercancía fuerza de trabajo para sobrevivir. Al contrario de la idea de que sería un sujeto natural y transhistórico, el sujeto desposeído es resultado de un proceso histórico. Es el efecto de un proceso de constitución, «un producto artificial de la historia moderna» (Marx, 1982a:950).

La violencia es «la partera» del capitalismo y la formación del sujeto desposeído como proletariado libre estuvo determinada por la fuerza productiva de la violencia. La emergencia del proletariado libre obedece a dos razones complementarias: es un sujeto liberado de la sujeción feudal y un sujeto privado de los medios de producción, por tanto, aparece como un sujeto suelto. El sujeto libre es una especie de sujeto sin objeto. Representa una masa desobjetivada, producto de la escisión entre el sujeto y sus objetos, del trabajador y su medio de trabajo, de cada persona respecto de las demás, de la sustancia de las cosas respecto de sus valores, del trabajo vivo y el trabajo muerto objetivado, del trabajo y el trabajo abstracto, pero la unidad escindida se restablece violentamente (Marx, 1982b), de tal suerte que se invierten los términos de la relación y el sujeto pasa a ser objeto y el objeto se convierte en sujeto: el objeto o producto de la actividad creadora 
del hombre, que debiera estar al servicio del hombre, se transforma en un sujeto, en capital, y pasa a ser dominante sobre el hombre mismo, al que transforma en objeto, se torna en el verdadero sujeto de la historia dentro del capitalismo. El capital impone sus leyes sobre a los sujetos que lo han creado y ahora se encuentran objetivados, cosificados, por lo que se precisa, teórica y prácticamente, reinvertir esa relación para poner la realidad sobre sus pies.

En contraposición a las ideas que atribuyen la concentración de los medios de producción en pocas manos a la existencia de una minoría industriosa y ahorrativa, el análisis histórico marxista situado en los umbrales del capitalismo demuestra que la violencia es la condición de posibilidad del capital y el capitalismo. Es una acumulación y una violencia originarias en el sentido de que son la prehistoria del capitalismo y a la vez significan la condición de posibilidad para el despliegue del capitalismo. La acumulación originaria es el «proceso histórico de escisión entre productor y medios de producción» (Marx, 1982a:893). La liberalización del sujeto, la formación del proletario libre, deviene de la escisión entre productores y medios de producción como requisito para la gestación del capitalismo. Estos son los presupuestos fundamentales, al instaurar un hiato entre productores y medios de producción. Al instituir esa fractura, la violencia propicia la depauperación de las masas y conduce a los expropiados hacia los espacios de producción de plusvalía.

Marx toma como ejemplo Inglaterra, desde el siglo XV hasta avanzado el siglo XIX, para investigar las formas de violencia que se ensañaron contra la población rural, mayoritaria en el feudalismo, por lo que los campesinos son expulsados de sus tierras y que a la postre engendrarían el modo de producción capitalista. El despojo de la tierra y de los instrumentos de trabajo 
convierte a los expropiados en proletarios libres, y el suelo expropiado es anexado a las tierras de los grandes terratenientes. La privatización de terrenos comunales, una conversión de lo común en dominio privado, se dio tanto por la violencia directa como por intermediación de la ley. A través de esta vía, «la ley misma se convierte ahora en vehículo del robo perpetrado contra las tierras del pueblo» (Marx, 1982a:906), en particular mediante las célebres leyes de cercamientos de terrenos comunales (enclosure acts). Con el despojo masivo se configuró el trabajador libre y también un nuevo sujeto del consumo. El naciente proletariado aparte de estar forzado a vender su fuerza de trabajo ahora está igualmente forzado a abastecerse de víveres en el mercado. Otrora, el campesinado producía sus propios medios de vida, ahora tenía que comprarlos.

La violencia primigenia prohijó a un sujeto escindido por las dinámicas de la producción y la reproducción, de una parte, el productor de mercancías preñadas de plusvalor y, de otra parte, un comprador de las mercancías necesarias para subsistir y vivir acorde a la cultura de su tiempo. La expropiación de los productores directos, o más específicamente, «el aniquilamiento de la propiedad privada que se funda en el trabajo propio, esto es, la expropiación del trabajador» (Marx, 1982a:967), deriva en la transmutación de los trabajadores expropiados en obreros bajo el mando de los industriales concentrados en las ciudades, de lo cual se deduce la diferenciación entre las clases fundamentales del capitalismo naciente, burguesía y proletariado, pero de igual modo se deriva la formación de proletarios rurales como jornaleros subordinados a los terratenientes. A su vez, la violencia originaria engendra un sujeto colectivo que jugará un papel importante en la reproducción del capitalismo, el llamado ejército industrial de reserva o población excedente relativa, una multitud de excluidos 
del ascendente mercado de trabajo que incluye categorías socialmente degradadas, como los mendigos, vagabundos o, inclusive, delincuentes.

La dinámica incesante de la acumulación de capital, formulada bajo la premisa delirante de «iAcumulad, acumulad!` (...) Acumulación por la acumulación, producción por la producción misma» (Marx, 1987a:735), tiene como necesario correlato la acumulación de la miseria: «La acumulación de riqueza en un polo es al propio tiempo, pues, acumulación de miseria, tormentos de trabajo, esclavitud, ignorancia, embrutecimiento y degradación moral en el polo opuesto, esto es, donde se halla la clase que produce su propio producto como capital» (Marx, 1982a:805). Por ser inmanente al proceso de valorización, la miseria del trabajador no es exterior al capital.

El capitalismo requiere al sujeto despojado y excluido por la fuerza de la violencia expropiatoria. El ejército de marginados tiene asignado funciones económicas que contribuyen a la reproducción del capital. La sobrepoblación relativa es una fuente inagotable de fuerza de trabajo a disposición del capital (Marx, 1982a) que podrá renovar o reemplazar a los trabajadores de conformidad a las necesidades que marquen los ciclos económicos. Asimismo cumplen una función política relevante cuando es usada como dispositivo de despolitización de los trabajadores y justificación para que el capital colectivo mantenga bajos niveles salariales o incluso los disminuya y para contener o neutralizar políticamente al ejército obrero activo ante la amenaza del desempleo y la abundancia de trabajadores de relevo disponible en abundancia en el mercado laboral.

Analizar la dimensión jurídica de la acumulación originaria devela la aplicación de medidas legales con el fin de someter a los desposeídos a las exigencias del capitalismo en construcción. La naciente burguesía recurre 
al poder del Estado y a la fuerza de la ley para crear un estado de disciplina social generalizado, que incluía castigos ejemplares a los mendigos y vagabundos, quienes según las leyes a modo eran recluidos, esclavizados, torturados y ahorcados. La gestación jurídica del capitalismo se funda en leyes terroristas y en dispositivos políticos de control y disciplina sociales.

Entre el amplio repertorio de métodos de la acumulación originaria también se incluye la violencia de la ley y el poder del Estado para hacer posible que la burguesía imponga la subordinación del trabajador al régimen del capital y con ello reproducir las condiciones de explotación. De manera acusada, las normas legales se diseñan con la intención de garantizar la disciplina de los trabajadores que están insertos en actividades productivas: «La burguesía naciente necesita y usa el poder del estado para 〈regular el salario, esto es, para comprimirlo dentro de los límites gratos a la producción de plusvalor, para prolongar la jornada laboral y mantener al trabajador mismo en el grado normal de dependencia. Es este un factor esencial de la llamada acumulación originaria» (Marx, 1982a:922923). El sistema jurídico establece medidas de sujeción de los trabajadores y de criminalización de las asociaciones obreras para inhibir la posibilidad de que la fuerza de los trabajadores se traduzca en fuerzas políticas desestabilizadoras.

En primera instancia, el análisis marxista se sitúa en Europa, cuna de la modernidad capitalista, después se amplía fuera de ese continente, hacia el sistema colonial, ámbito estratégico para la expansión mundial del capitalismo y soporte del proceso industrial en ciernes. La violencia colonial significó un capítulo crucial en el proceso de acumulación originaria y fue la base de la formación de enormes fortunas que contribuyeron al proceso de industrialización. El sistema colonial representa un papel decisivo 
puesto que en los territorios conquistados se generaron riquezas extraordinarias que fueron saqueadas de las periferias y transferidas de manera sistemática a las metrópolis europeas:

El descubrimiento de las comarcas auríferas y argentíferas en América, el exterminio, esclavización y soterramiento en las minas de la población aborigen, la conquista y saqueo de las Indias Orientales, la transformación de África en un coto reservado para la caza comercial de pieles-negras [esclavos], caracterizan los albores de la era de producción capitalista. Estos procesos idílicos constituyen factores fundamentales de la acumulación originaria» (Marx, 1982a:939).

Así, la transferencia de la riqueza ha sido posible merced a la expropiación de la tierra, la esclavización, el sepultamiento de los indígenas en minas y plantaciones. La violencia de la explotación sobre el trabajo asalariado es el sustrato del despliegue de la gran industria, lo cual incluye la explotación del trabajo infantil y el trabajo nocturno mediante el sistema de relevos entre turnos diurno y nocturna con la intención de intensificar la sustracción de un plusvalor acrecentado (Marx, 1988a).

Luego de develar que el misterio del plusvalor resulta de una relación entre capital y trabajo tensada por una violencia económica cotidiana reproducida incesantemente que obliga al trabajador a vender su fuerza de trabajo, Marx esclarece la violencia fundacional que está sentada en la acumulación originaria en los métodos de despojo que separan a los productores directos de sus medios de producción y subsistencia que los obliga a proletarizarse; a ello agrega el sistema colonial de expropiación de territorios y saqueo de la riqueza con formas extremas de explotación que 
incluyen el esclavismo, de tal suerte que la acumulación originaria y el colonialismo son la clave de la génesis del capitalismo y de la procreación de los sujetos fundamentales, los poseedores de la fuerza de trabajo en venta que permanentemente estarán atados a una relación de dependencia para estar recreando el plusvalor. Origen y desarrollo del capitalismo están singados y no se pueden entender sin la trama de la violencia.

\section{Violencia contratendencial}

La expansión del capital por los confines de la tierra bajo el inexorable dispositivo de la violencia trae a colación una y otra vez la obra de Marx. La llamada acumulación originaria no puede mantenerse como un dato encapsulado en el pasado remoto, el tránsito del feudalismo al capitalismo, sino como un método que llegó para quedarse, pues el despliegue del capitalismo requiere reiniciarse permanentemente mediante la escisión entre los productores directos y sus condiciones de subsistencia, en los ámbitos donde dicha separación no se ha consumado a fin de que el capital aparezca como una relación rediviva. Asimismo a través de la conquista de regiones periféricas donde los capitales metropolitanos encuentran espacios de valorización idóneos para colocar sus excedentes y explotar los reservorios de fuerza de trabajo barata y la biodiversidad. Más que formas propias de un tiempo pretérito, entre los siglos XV y XVIII, como se describe en el capítulo XXIV de El capital, en alusión a la génesis del modo de producción capitalista, la violencia del capitalismo se reedita de modo ininterrumpido y funge como motor propulsor de su incesante despliegue, pareciera ubicarse dentro de una cápsula del tiempo que asiste de manera puntal a la 
producción del presente, en un eterno retorno. En su constante desarrollo, el capitalismo implementa la violencia con el objeto de lograr la conquista de territorios, apropiarse de bienes naturales y medios de producción, conquistar mercados, explotar reservas de fuerza de trabajo barata, privatizar bienes comunes, etcétera. La violencia capitalista es un presupuesto histórico, el punto de partida y, a la vez, es el mecanismo permanente o estrategia recurrente de la acumulación de capital.

A partir de la teoría del valor trabajo, Marx (1987b) dedujo la ley de la tendencia decreciente de la tasa de ganancia debido al ineludible incremento de la composición orgánica de capital («la disminución relativa de la parte variable del capital con respecto a la constante»), contradicción que tiene que ser resuelta mediante diversas estrategias que contradigan a la ley tendencial, como el incremento del grado de explotación del trabajo, la reducción del salario por debajo de su valor, el abaratamiento de los elementos del capital constante, la sobrepoblación relativa, el comercio exterior y el aumento del capital accionario (Marx, 1987b).

Más específicamente, Marx argumenta que el capital emprende una expansión hacia afuera, para abarcar áreas que no están bajo la égida del capital. Ante la tendencia decreciente de la tasa de ganancia, el mal que aqueja al capitalismo en su desarrollo contradictorio, se indica que la salida es: «expandir constantemente el mercado, de modo que sus vinculaciones y las condiciones que las regulan asuman cada vez más la figura de una ley natural independiente de los productores, se tornen cada vez más incontrolables. La contradicción interna trata de compensarse por expansión del campo externo de la producción» (Marx, 1987b:314). La dialéctica entre el plano interno, referente al capitalismo metropolitano, y la salida externa, con alusión a las regiones periféricas, será una pista de análisis que seguirán los teóricos del capitalismo. 
Para la izquierda y el nacionalismo afincado en los países subdesarrollados la cuestión del imperialismo ha sido un tema nodal, retomado desde Lenin (1973), Hilferding (1963), Hobson (1981), Bujarin (1971) y subsiguientes. La comprensión más cabal acerca del imperialismo parte de la caracterización de Lenin sobre el predominio del monopolio y la explotación de las colonias, las semicolonias y los países dependientes por los países industrializados. El capitalismo se desenvuelve entre guerras en distintos niveles: entre las potencias a escala mundial; de los pueblos oprimidos contra el imperialismo en pos de la liberación nacional, y guerras civiles de los trabajadores contra el capital en el seno de países industriales. La economía mundial se configura por la competencia de los Estados-nación junto con sus monopolios nacionales, aunado al dominio político, diplomático y militar de los países centrales sobre los periféricos — colonias, semicolonias y zonas de influencia. En la era del predominio del capital monopolista la violencia se recrudece a causa de guerras, golpes de Estado, fraudes electorales.

El sistema capitalista mundial se reproduce incesantemente por medio de la violencia. En ese curso, los países periféricos han estado sujetos al más flagrante saqueo; sin esa violencia el capitalismo no puede reproducirse, es un sistema arraigado en la violencia. Rosa Luxemburgo lo advertía: «El capital no puede desarrollarse sin los medios de producción y fuerzas de trabajo del planeta entero. Para desplegar, sin obstáculos, el movimiento de acumulación, necesita los tesoros naturales y las fuerzas de trabajo de toda la Tierra» (Luxemburgo, 1967:177). Con el agregado de que los yacimientos naturales y del trabajo apetecidos para amplificar los ciclos de acumulación subyacen en formas pretéritas de producción «precapitalistas», razón por la que el capital no cejará en su compulsión de apropiarse de las fuentes de la riqueza, los territorios y la sociedad. El desarrollo del 
capitalismo, en su lógica interna, requiere de un entorno integrado por formaciones sociales periféricas, subdesarrollados, de las cuales se alimenta y las va incorporando a la acumulación mundializada con formas de intercambio desigual que le permite expropiar territorios, absorber el excedente generado, explotar el trabajo vivo y deglutir los bienes naturales.

Históricamente, esta contradicción dialéctica ha sido un requisito en la conformación de la acumulación mundial capitalista. Para el desarrollo del capitalismo, desde los orígenes hasta el presente, la violencia ha resultado el método más constante que sustenta la acumulación. Las conquistas, el esclavismo y el imperialismo en cuanto métodos son funcionales a la confrontación entre el capitalismo moderno y civilizado con las economías vernáculas consideradas prehistóricas o premodernas ajenas a las dinámicas de acumulación. El hecho es que el capitalismo siente la necesidad de expropiar sus medios de producción y trabajadores, además de abrir un espacio de mercado para colocar sus mercaderías. Por ello, hay que «aniquilarlos como formaciones sociales independientes» (Luxemburgo, 1967:180).

Referente al despliegue del imperialismo, la burguesía cobró conciencia de que el latrocinio de la acumulación original de capital posibilitó la postrera acumulación, y para hacer que el motor de la acumulación continuara activado, se requería continuar su repetición (Arendt, 1998:135). No se trataba de un hecho recurrente que resurgía por la fuerza del automatismo, sino por obra de un proyecto, de una gran empresa del capital colectivo, que va tejiendo el mercado mundial e impone la ley de hierro del capital.

La acumulación mundial de capital tiene como eje troncal la transferencia de valor de la periferia subdesarrollada hacia el centro capitalista desarrollado. Esto es posible por la continua renovación de la acumulación 
originaria, una «acumulación originaria permanente», para beneficiar al centro del sistema mundial:

Cada vez que el modo de producción capitalista entra en relación con modos de producción precapitalistas a los que somete, se producen transferencias de valor de los últimos hacia el primero, de acuerdo con los mecanismos de la acumulación primitiva. Estos mecanismos no se ubican, entonces, sólo en la prehistoria del capitalismo; son también contemporáneos» (Amin, 1985:11).

Bajo el influjo de la fórmula del desarrollo desigual y combinado, los países ubicados en las periferias del sistema mundial, procedentes del pasado colonialista y ahora subsumidos en la fatalidad histórica de un subdesarrollo y dependencia que les obstruye el ascenso sobre la escaleta del desarrollo capitalista, en pos de un estadio de capitalismo avanzado con progresión social relativa, permanecen de modo inexorable postrados en calidad de países sometidos por el yugo de las oligarquías y el imperialismo:

La relación económica con la metrópoli perpetúa su situación de subdesarrollo, lo que los obliga a mantenerse en una situación que podría ser calificada de acumulación primitiva permanente (...) Sus partes constituyentes - el sector capitalista y el no capitalista — constituyen dos modos de producción que juntos conforman una sola formación socioeconómica subcapitalista» (Bartra, 1999:9).

Un relato que no se queda anclado en los orígenes del nuevo mundo y su arribo a la constitución de Estados nacionales modernos e independientes, sino que se hace extensivo a las diversas etapas de expansión del capitalismo. 
Se observa que ha persistido la idea de países precapitalistas o sectores no capitalistas subsumidos a la vorágine de la acumulación de capital: «el capitalismo está atendido, aún en su plena madurez a la existencia coetánea de estratos y sociedades no capitalistas» (Luxemburgo, 1967:329). Idea que puede ser refutada, dado que el capitalismo central o metropolitano subsume territorios, recursos, trabajo vivo, y los canaliza hacia la acumulación capitalista mundial, internalizándolos en su lógica de valorización. La relación entre el núcleo capitalista y una periferia no capitalista del sistema capitalista se disuelve cuando se asume que el capitalismo se expande en el mercado mundial y conquista territorios y pueblos otrora ajenos a su evolución, pero prontamente subsumidos y refuncionalizados para efectos de la valorización. Son funcionales al desarrollo del capitalismo, pese a que no haya desarrollado una revolución industrial y no se haya generalizado el trabajo asalariado. De ahí su carácter dependiente y subdesarrollado, que no será superado sino con la superación del propio sistema capitalista mundial.

\section{Actualidad de la violencia pretérita}

El debate contemporáneo sobre acumulación capitalista tiene como punto de referencia el hecho de que la apropiación violenta, el despojo, los cercamientos, no remiten a un acontecimiento originario o primitivo, que se reedita como si el capitalismo estuviese de modo continuo renaciendo, sino que es un rasgo congénito, estructural, del capitalismo que lo acompaña en su desarrollo y, por tanto, la violencia es una fuerza motriz continua, permanente o reiterada, a la sazón un fenómeno irremediablemente vigente en el capitalismo tardío de los siglos XX y XXI. 
Imbricado con la modernidad, el capitalismo siempre ha mostrado apetencia de actualidad. El vértigo de la novedad es la insignia de la modernidad capitalista, un pletórico afán de renovación y búsqueda incesante de la máxima ganancia posible; no obstante, pasado y presente se funden y coagulan en la cristalización de la novedad. La actualidad permanente aparece como acto fundacional que recrea etapas, fases y eras que renuevan el rostro del capitalismo, cuya simiente está enraizada en la exacción del plusvalor. Para continuar renovándose requiere resucitar los añejos métodos de la acumulación originaria, que parecen contradecir al vigoroso capitalismo tecnocientífico y progresista. En pleno siglo XXI, una nueva generación de estudios críticos en torno al capitalismo respaldados en la tradición marxista ha dado cuenta de la actualización de los métodos de despojo de tierras campesinas en los confines del mundo para reconvertirlas de nueva cuenta en bienes capitalizados que formarán parte de los activos de las grandes corporaciones agroindustriales, petroleras, mineras, constructoras, turísticas y demás actividades donde se arraigan las ganancias extraordinarias sustraídas de los recursos naturales desregulados y el trabajo barato. Un dato inescrupuloso es la reanimación de los métodos de la acumulación originaria, la privatización de bienes y servicios públicos, la mercantilización de derechos sociales, los sistemas de salud pública, los fondos de pensiones y la educación, entre otros. La puesta al día de tales métodos significa la conversión de los restos, los residuos del común, en mero dominio privado, y por ello han sido pensados y tratados como nuevos cercamientos. Como lo expresará Luxemburgo y lo ratifican además autores contemporáneos, el capital se ve compelido a actualizar las estrategias de la acumulación originaria para avanzar y conquistar los espacios donde no ha logrado expandir del todo la férula del mercado (Galafasi, 2016). 
El concepto de acumulación por desposesión, también enunciado como acumulación por despojo, ha ganado buena fortuna en los estudios críticos y puesto en tela de juicio la colosal expansión del capital global que busca apropiarse de territorios para sustraer rentas, es decir, ganancias extraordinarias. Vale la pena señalar que tiene un gran potencial descriptivo, por cuanto evidencia la contradicción de resucitar métodos violentos del capitalismo originario en un mundo que presume de progreso, democracia y libertad. Sin embargo, el concepto no es del todo profundo en sus capacidades analíticas, en su consistencia teórica, pues elude el meollo del asunto. La cuestión radica en que el proceso de acumulación no se explica, no está determinada por el despojo.

La acumulación originaria acaecida entre los siglos XV y XVIII alude a un proceso esencialmente violento mediante el cual los bienes comunes son saqueados para ser privatizados. El despojo se inscribe en un proceso histórico, un momento de gestación, donde la riqueza es apropiada, atesorada, y en tal sentido representa una fase preparatoria en la que la riqueza es acumulada para luego convertirla en capital y entonces a través de la explotación del trabajo vivo será posible la creación de la plusvalía, por lo que se transforma en acumulación directa y no mediante la fertilidad o riqueza inmanente de los recursos naturales. Históricamente, el despojo de los medios de producción, funciona como un requisito para la formación de capital y la activación del proceso de producción. La violencia funciona, entonces, como una potencia económica. El despojo opera como la destrucción del productor directo: al campesino se le arrebatan las tierras, al artesano se le desmantela el taller, al productor se le substraen los medios de producción. Este despojo aparece como una liberación forzada de medios de producción con objeto de que el productor directo autónomo se 
someta al régimen de producción burgués, quede sujeto a los medios de producción transformados en capital y se convierta en un nuevo sujeto social: el proletariado. Empero, el proceso de despojo no es todavía acumulación. El despojo será perfectamente funcional al proceso de acumulación cuando la fuerza de trabajo, los medios de producción y las materias primas se conjuguen en la dinámica de reproducción de riqueza bajo la pauta capitalista, ya sea que tome la forma de una empresa agrícola, minera o industrial. La acumulación se vuelve un proceso ampliado sobre la base de la explotación del trabajo.

El saqueo de las comunidades, de los pequeños productores, independientemente de que estén organizados de forma familiar o comunal, el saqueo de sus bienes (tierra, subsuelo, agua, biodiversidad, saberes, paisajes, cultura e identidad) es un mecanismo violento de separación entre el sujeto productor y el objeto de trabajo, puede entenderse como un proceso de destrucción de los ámbitos de comunidad y los conjuntos familiares, pero a su vez funciona como un proceso constitutivo, en tanto formador de capital, puesto que incorpora al proceso de acumulación aquella riqueza pillada, apropiada con violencia, para transformarla en medio de producción y canalizarla en el proceso de valorización más amplio. Así, la clave de la acumulación no es el saqueo o despojo, sino la plusvalía, la explotación del trabajo vivo.

Para la gestación del capitalismo, el despojo resulta de un momento históricamente necesario y explica su postrero desarrollo; no obstante, no se detiene en esa etapa primitiva, sino que, en su desarrollo, el capitalismo recurre una y otra vez, con mayor o menor intensidad, al despojo. De modo sintomático, en la etapa del capitalismo tardío, donde se experimenta la cuarta revolución industrial (descrita como Industria 4.0), el augurio es 
que el capitalismo llegará a su término, tarde o temprano, recurriendo, una y otra vez, al vetusto método del despojo, por lo que además de una necesidad histórica del desarrollo capitalista está inscrita en su formulación y despliegue lógico de la relación de capital. De ahí que el despojo es una etapa violenta de gestación y despliegue de la formación de capital; pero la clave, el punto crítico de referencia para descifrar la violencia primigenia en el capitalismo ha sido, sigue siendo, la explotación del trabajo asalariado, el culmen de las relaciones sociales dominantes.

La expansión del capital rentista en el capitalismo contemporáneo no es originaria en los mismos términos descritos por Marx, referentes a una época particular de gestación del sistema. Aunque la persistencia de la acumulación originaria en el presente, en tanto método violento para despojar medios de producción, liberar a los productores y proletarizarlos, da cuenta de un capitalismo insaciable que no termina de engullir su entorno y que recurre a mecanismos regresivos para hacer valer su prepotencia, así como cancelar cualquier espacio alternativo que pretenda reproducirse de manera autónoma, sin conexión con el automatismo del mercado y el gran dinero.

\section{Periferias redescubiertas}

El expediente del despojo y la guerra de amplio espectro, formas de acumulación originaria permanente, está abierto en las periferias del mundo. Las guerras emprendidas por las alianzas imperiales, Estados Unidos a la cabeza, han reeditado las guerras de conquista sobre aquellos territorios geoestratégicos dotados de yacimientos petrolíferos y gasíferos que apetecen los capitales que medran con la preponderancia de los combustibles 
en el modo de acumulación fosilizado. Sin embargo, también se realizan guerras económico-políticas en zonas preferentes donde pierden terrenos los gobiernos neoliberales afectos al imperio, como ha sucedido en el cono sur latinoamericano, con golpes virtuales de Estado (Honduras, Paraguay) o legislativos (Brasil) y acometidas de la nueva derecha (Argentina, Ecuador) y el acoso mediante la guerra económica en la principal reserva petrolera del orbe (Venezuela). La guerra económico-política en México no ha sido necesaria gracias al entreguismo perpetuo de su clase política.

A la manera de Galeano (1971), las venas de América Latina siguen abiertas, desangrando el excedente generado, el trabajo vivo y los bienes naturales. Los megaproyectos se han instalado como la expresión más avanzada de las nuevas tecnologías de saqueo y han horadado los territorios despojados a las comunidades para acceder a minerales por medio de la remoción de grandes cantidades de tierra con explosivos y maquinaria, lo cual forma cráteres terrenales que pueden llegar a ocupar inmensas extensiones a lo ancho y con gran profundidad. El tajo a cielo abierto es el performance del pillaje moderno, donde se remueven grandes cantidades de tierra para sustraer pequeñas cantidades de oro y otros minerales, incluyendo tierras raras, con un alto costo ambiental, pues se vierten grandes cantidades de sustancias químicas y de agua, lo que genera una estación terrena de ecocidio. Los pueblos afectados están en resistencia por toda la región sin lograr revertir tal avanzada tutelada por los estados, que dicen obtener beneficios para los pueblos y países actualizando los discursos empolvados e inciertos del desarrollismo. Algo semejante puede decirse de una gran variedad de megaproyectos, como los hidroeléctricos, las carreteras, el gran turismo (destruyen manglares, contaminan playas), la especulación inmobiliaria y la urbanización salvaje, etcétera. 
El despojo de tierras, su acaparamiento y transformación en grandes desiertos verdes, modernas plantaciones de monocultivo de exportación, con tecnologías de punta, incluyendo semillas genéticamente modificadas y otros implementos de la segunda revolución verde, presenta un escenario donde el hambre de tierras, la geofagia del capital, contrasta con el despoblamiento, la pobreza y el hambre de pueblos campesinos e indígenas. Otrora, la agricultura era un sector irrelevante para el capital, se consideraba una suerte de reservorio donde pervivían las comunidades agrarias, las economías familiares, sujeta a determinadas políticas de regulación y asistencialismo, pero no era visto como negocio para el gran capital. A pesar de que había grandes agroindustrias conectadas a la economía global, la tierra no estaba en su radar; con todo, los embates especulativos y el reacomodo de excedentes de capital, detectan la importancia estratégica de las tierras, y a partir de 2002, y con más fuerza desde 2008 con la crisis alimentaria global, se abre una nueva colonización de tierras o acaparamiento de tierras (land grabbing). Es una embestida a nivel planetario que toma mal parados a los campesinos, comuneros y pequeños productores. Esto incluye operaciones de robo sobre tierras baldías o subutilizadas que el capital se adjudica y refuncionaliza bajo el peregrino argumento de que, siendo más eficientes y productivos, dotados de tecnologías de punto, habrán de resolver el problema acuciante del hambre. Dichas tierras en realidad están habitadas y son cultivadas, ya sea a la manera tradicional, campesina, o de manera medianamente tecnificada. No obstante, son expropiadas por quienes son sus legítimos poseedores, los llamados pueblos originarios o comunidades campesinas, que hacen del cultivo la forma central de la cultura material de la reproducción de los pueblos. Es una historia de violencia y saqueo que recuerda y profundiza el colonialismo. 


\section{Finisterre}

Se ha dicho con sarcasmo que es más fácil pensar en el fin del mundo que en el fin del capitalismo (Jameson, 2000; Žižek, 2014). No es para menos, el capitalismo siempre busca vías de escape, nuevos espacios de valorización, así se esté colapsando el planeta. Por lo que los agoreros del colapso final del capitalismo tienen que estar replanteando las fechas fatídicas del sistema, para el momento improbable cuando existan «las condiciones objetivas» del derrumbe (Wallerstein et al., 2015). Los excedentes de capital se han movilizado frenéticamente para buscar rentas en los sectores financiero, inmobiliario, extractivo, energético, agroindustrial, entre otros. En contraste con la utopía tecnocrática de una sociedad del conocimiento que haría prescindible el trabajo humano y la naturaleza, el capital rentista busca valorizar espacios y recursos alojados en los territorios que han venido escaseado o que están monopolizados para impedir su acceso abierto y entonces poder sustraer elevadas rentas merced a las altas cotizaciones internacionales. En el presente, la ganancia extraordinaria además de sectores de punta en sectores productivos apuntalados por las tecnociencias en la informática, la biotecnología, la nanotecnología, la ingeniería genética y la inteligencia artificial, encuentra un oasis en sectores que se consideraban anclados en formas pretéritas del desarrollo capitalista. En estas circunstancias, la renta significa una ganancia derivada del despojo, cercamiento y privatización de bienes naturales, la biodiversidad que representaba un espacio común para la reproducción social de pueblos originarios, comunidades campesinas y clases populares (Bartra, 2016). Una vez más se implementan mecanismos violentos, la potencia económica del despojo, para convertir en capital el conjunto de bienes residuales en posesión de 
sectores subalternos. Los bienes comunes son arrancados de sus usufructuarios y poseedoras para transformarlos en riqueza privada: yacimientos petrolíferos y gasíferos, reservas minerales, tierra fértil, agua dulce; la biodiversidad, el manto territorial y la variedad de bienes naturales escasos.

La crisis del capitalismo en los últimos años ha sido abordada, principalmente, como un problema del de la expansión del capital financiero desregulado que en su desenfreno y codicia acomete embates especulativos que redundan en estallidos de burbujas especulativas que ocasionan severos quebrantos, falta de liquidez y destrucción de capitales, o, en su defecto, se interpreta como una recesión económica dentro de los ciclos de la economía mundial, una caída vertiginosa del la actividad económica y de insolvencia de los agentes económicos que reclama el salvamento estatal para reanimar el crecimiento y recomponer la dinámica económica.

El último tramo del siglo XX y lo que va del XXI se ha caracterizado por la emergencia de una crisis de talante civilizatorio no sólo por el hecho evidente de que el proceso toral de la valorización hace corto circuito y disloca las redes financieras y productivas tensadas en la economía mundial sino también porque los fundamentos ontológicos del capital, las fuentes primordiales de la riqueza, la naturaleza y la humanidad, están al borde del colapso (Márquez, 2015).

La antinomia producción-reproducción que aqueja estructuralmente al capitalismo cobra mayor rejuego con la crítica paradoja entre sobreproducción y subconsumo. El desarrollo incesante de las fuerzas productivas propicia recurrentemente una abundancia de mercancías, por el contrario, la desvalorización de la fuerza de trabajo, incluso a niveles fisiológicos de subsistencia en grandes zonas del mundo, deriva en subconsumo popular y una consecuente crisis de realización, entonces se produce más de lo 
que se puede consumir, pero la crisis actual no es propiamente de escasez. En el reino de la abundancia, la sobreexplotación del trabajo degenera en pobreza, hambruna y muertes por inanición. En otros ámbitos se registran cuadros de escasez, sobre todo de determinados recursos naturales no renovables, que son apropiados por el capital extractivo y utilizados como mercancías especulativas para gestar ganancias extraordinarias, por lo que esta forma de escasez y la renta territorial se convierte en el gran referente del capital, al mismo tiempo en que una plétora de mercancías inundan los mercados de consumo donde grandes franjas de la población son negados como concurrentes al considerarse consumidores insolventes.

En fase decadente, el capitalismo contemporáneo se precipita por una profunda crisis civilizatoria, que anuncia el fin de los tiempos, no por la realización de la emancipación humana sino por la pulsión de muerte y la devastación de la naturaleza. En el despliegue inexorable de la lógica de valorización exacerba las formas pretéritas de su gestación, la acumulación originaria, mediante el despojo, y sus formas depredadoras del trabajo vivo, la superexplotación. La simbiosis entre violencia y acumulación nos recuerda que el capitalismo nace «chorreando sangre», pero en la proximidad del fin de los tiempos se asienta en una profunda crisis civilizatoria, la modernidad capitalista se decanta por la barbarie y amenaza las fuentes de la riqueza, la naturaleza y la humanidad.

El capitalismo del fin de los tiempos es un organismo planetario pletórico de violencia en contra de las personas consideradas sobrantes, improductivas, ineficientes, anacrónicas, y en contra de la naturaleza, tratada como un insumo productivo. La principal fuerza productiva, el proletariado, se aviene entonces como como una mera subjetividad sin sustancia, a la cual no sólo le es despojada la capacidad de controlar sus condiciones 
de existencia, sino que también está siendo desposeída de un entorno natural vivible, donde pueda reproducirse en conjunción con la naturaleza y además está siendo desprovista de la capacidad de transformar su mundo. No sólo pierde el control sobre la sustancia sino que su propia subjetividad es vulnerada, enajenada, aniquilada.

\section{Despojo, un oxímoron}

Una palabra clave del capitalismo contemporáneo es la de despojo, irresolublemente derivada de la acumulación originaria por medio de la violencia, la invasión y el despojo de Marx (2007). La nueva versión de despojo alude a la violencia contra las comunidades y el saqueo de la naturaleza, que más que una anomalía o perversión del sistema, son un mecanismo permanente, incluso una condición de posibilidad de existencia del capitalismo, como lo planteara, a su vez, Luxemburgo. La discusión sobre la acumulación por despojo (Harvey, 2003) y la acumulación originaria permanente (Amin, 1985) está a la orden del día.

La reinterpretación de la crisis del capitalismo concita diversas discusiones que retrotraen ideas que fueron sembradas para entender el tiempo pretérito de la acumulación y que aportan claves para dilucidar el presente. A partir de la idea de un «nuevo imperialismo», la formulación sobre la acumulación de David Harvey ha ganado gran profusión en los medios académicos, políticos y periodísticos, según la cual la acumulación no obedece tanto a la reproducción ampliada de capital, puesto que enfrentaría obstáculos en un contexto de crisis de sobreacumulación, por lo que la acumulación encuentra una válvula de escape en el dispositivo renovado de 
la desposesión, que haría insostenible la premisa marxista de «confinar la acumulación originaria a la prehistoria del capitalismo. El capitalismo habría dejado de existir hace mucho tiempo si no hubiera emprendido nuevas rondas de acumulación originaria, principalmente mediante la violencia del imperialismo» (Harvey, 2014:297).

En términos gruesos, la discusión sobre la naturaleza de la crisis del capitalismo contemporáneo se remite a la noción de sobreacumulación de capital para desentrañar los obstáculos de la reproducción ampliada del capital. Esta interpretación de la crisis parte de la idea de que el capitalismo experimenta una capacidad acrecentada para producir valor, pero enfrenta el problema de mantener ciclos de acumulación donde se garanticen márgenes óptimos de rentabilidad. No obstante, en un contexto donde lo que prevalece es la tendencia hacia el decrecimiento de la tasa de ganancia se debe considerar que la generación de la masa de valor por el capital social impelida por el incesante progreso científico-tecnológico propicia que la producción de mercancías incorpore una cantidad de fuerza de trabajo cada vez menor y en consecuencia que se reduzca drásticamente la producción de valor, es decir, el supuesto de la sobreacumulación de capital y de su consecuente argumentación.

La llamada acumulación originaria estudiada doctamente por Marx se inscribe en un proceso histórico en el que los campesinos ingleses son, en efecto, desposeídos de las tierras comunales y, también, obligados a vender su fuerza de trabajo al capital. Un doble movimiento que sienta las bases de las relaciones capitalistas de producción. La desposesión significa una violencia social que sucesivamente se hará presente en la reproducción de las relaciones de producción capitalistas. El capitalismo naturaliza la desposesión y la convierte en un automatismo social, mientras que el conjunto de la sociedad inmersa en las dinámicas de reproducción se ve compelida 
a asimilarla, incluso desde una cierta lógica fetichista, como si fuese parte del entramado civilizatorio o de la naturaleza social del capitalismo que además incentiva la competencia intracapitalista, un mecanismo de supervivencia, como una fuerza progresista y un fin en sí mismo.

Esta acumulación originaria no se aplica de forma directa, al pie de la letra, pero como método violento se desenvuelve sin solución de continuidad entre los orígenes, expansión y contemporaneidad capitalista. De ahí que autores como Harvey y sus seguidores lo replanteen para imprimirle actualidad, pero también otro sentido. Derivado de ello, un punto importante para la discusión es que con la desposesión de bienes comunales, el capital no pretende mercantilizar la fuerza de trabajo, de por sí sobrante merced al desempleo estructural por el avance tecnológico. Más bien, el método responde a la propensión parasitaria del capital de apropiarse, sin reservas, del valor generado por otros capitalistas.

La mercantilización de los bienes comunes naturales y de los bienes nacionales que han sido producidos en el seno de relaciones sociales de tipo comunal (sean o no consideradas precapitalista o no capitalistas) y de bienes y servicios del ámbito de la economía estatal. Más aún, el expediente de la desposesión se amplifica a sectores ultramodernos, como las redes digitales, donde no pareciera manifestarse la violencia y donde predominan los grandes monopolios internacionales (Facebook o Google) que encarnan la vanguardia del progreso tecnológico, pero que en el fondo no dejan de apropiarse y mercantilizar aquello que es producido por otros. Esto es un cúmulo de información, datos e imágenes generados no por las propias corporaciones sino por la interacción de millones de usuarios de todo tipo que suelen comunicarse a través de estas redes. Al final de cuentas los grandes monopolios logran sustraer una ganancia extraordinaria, una 
conspicua renta tecnológica, signo del capitalismo que se desplaza sobre intrincadas redes integradas por un conjunto amplio de bienes intangibles, que en última instancia significa la apropiación de un valor generado por otros capitalistas que compran esa gran cantidad de dispositivos, información y formas de comunicación digital que mueven una porción creciente de las modalidades de producción, distribución y consumo.

Es sintomático de la complejidad del capitalismo contemporáneo que diversas formas emergentes de desposesión así consideradas no impliquen directamente la proletarización de los usuarios o afectados, hasta que no se conviertan directamente en trabajadores asalariados: en el caso de la desposesión de determinados bienes comunes, como los intangibles, no repercuta en la proletarización de los usuarios, porque en tanto consumidores de un bien o servicio no producen valor, puesto que la mercantilización de los bienes comunes naturales del pueblo campesino o indígena no deriva en su inmediata proletarización, pero sí en formas drásticas de exclusión de las relaciones sociales capitalistas. Entonces, la actual crisis del capitalismo no necesariamente significa una crisis de sobreacumulación, sino que, en un sentido más profundo, deviene de la producción menguante de valor, a la sazón la principal grieta del funcionamiento del sistema.

Para Marx, el supuesto básico es que el capital no es propiamente una cosa, ni menos aún el atributo de una cosa, sea un bien natural o un artefacto tecnológico, sino más bien una relación social mediada por cosas, las mercancías: «Pero el capital no es una cosa, sino determinada relación social de producción perteneciente a determinada formación histórico-social y que se representa en una cosa y le confiere a ésta un carácter específicamente social» (Marx, 1999:1037-1038). 
De tal suerte que racionalidad histórica de la acumulación originaria supone que el capital se va construyendo como una relación social que depende de la explotación del trabajo, y para hacer posible que se consolide y expanda como forma social dominante, requiere que los proletarios estén imposibilitados para recrear modos alternativos de producción de medios de subsistencia. La desposesión violenta de los bienes comunes sólo implica un aspecto crucial, la separación entre sujeto productor y objeto del trabajo, es decir, la procreación de una subjetividad sin sustancia, de un sujeto sin objeto, o de un modo más concreto, la separación de las condiciones de existencia, pero no necesariamente entraña un proceso de acumulación de capital definido por el mero acto de la expropiación, el hurto o el saqueo.

Es necesario introducir un matiz, en el capitalismo contemporáneo no se genera una proletarización en el sentido de formación de obreros para la fábrica o en un sentido más amplio de trabajadores asalariados en distintos sectores económicos. El desempleo estructural viene desdibujando la preponderancia del trabajo asalariado, pero en cambio sí se genera una proletarización masiva, en el sentido del sujeto sin sustancia, del sujeto despojado, excluido y necesitado, que sólo dispone de su propia fuerza de trabajo para subsistir, con el atenuante de que los mercados laborales no lo requieren.

Las dinámicas de reproducción social se fracturan, y emerge una figura variopinta que sigue distintas rutas para sobrevivir, sea como pequeño productor, jornalero migrante, migrante internacional, vendedor callejero, criminal y muchas expresiones de sobrepoblación relativa, que incluye a comunidades autónomas que no están envueltas en la producción mercantil. Además, se de una proletarización en el sentido no sólo de la desposesión 
directa de los medios de producción y subsistencia, sino también de desposesión de la biomasa y los ecosistemas, del entorno natural, que permite la reproducción humana.

El abordaje de la acumulación originaria como un proceso de desposesión que posibilita generar las condiciones para la apropiación privada de riqueza sin consideración de que el cometido era producir proletarios, elude la cuestión central del tejido de relaciones sociales basadas en la explotación y generación de plusvalor que subyacen al modo de producción capitalista. En el análisis de Marx se explica el despojo y la proletarización como condiciones necesarias para la capitalización.

Diversos autores han insistido en el carácter permanente, reiterado o perpetuo de la acumulación originaria, para no dejarla en la prehistoria del capital, sino como uno de los motores de la expansión del capitalismo más allá de sus fronteras territoriales y sociales, y para tal efecto ha sido sobre adjetivada como «acumulación originaria permanente» (Amin, 1985) o renombrada «acumulación por desposesión» (Harvey, 2003). Este argumento se desliza por la cuerda floja de la historia del desarrollo del capitalismo al pretender defender que el capital depende del saqueo permanente de los bienes comunes, en particular de los naturales. El problema es que para ciertos estudiosos el capital parece no depender ahora del proceso de producción sino más bien de los resultados inmediatos de dicho proceso, es una lectura de la posproducción o, mejor dicho, circulacionista, donde el capital no depende tanto de la existencia de fuerza de trabajo sino de la lucha entre los propios capitalistas por amasar riquezas. Todavía más: existe una lectura comunalista, que se remite a la comunidad ancestral o los pueblos originarios, a la madre tierra o la Pachamama, que también rememora a la economía fisiócrata, donde la naturaleza es la generadora 
de la riqueza, independientemente del trabajo vivo, del proceso de valorización, por lo que la naturaleza tiene un valor en sí misma, incluso tendría derechos propios según los constituyentes del buen vivir o sumak kawsay.

El punto crítico es que el capital no es propiamente una cosa sino una relación social y que al ser valor que se valoriza no puede abstraerse de las clases sociales ni de los mecanismos de explotación. De modo que no es extraño que las formas de pensamiento que pretenden elaborar una crítica del presente o de algunas de sus expresiones particulares, como la modernidad, el progreso, el crecimiento, el neoliberalismo o el extractivismo, al operar a expensas de un análisis fundamentado del desarrollo del capitalismo, resultan errados en su cometido, pues consideran al capital como si fuese una entidad extraña, una fuerza impuesta a la sociedad, sea a los pueblos originarios o a las comunidades, pero no como un producto histórico emanado de las relaciones sociales que configuran este contradictorio modo de producción.

Desde esa prefiguración, posmoderna o heterodoxa, no se alcanza a discernir con claridad el ámbito, el entramado de relaciones, donde se generan y despliegan las contradicciones del sistema ni los conflictos sociales que la caracterizan, por lo que las consecuencias políticas que de ello se extraen son erráticas o parciales. En esa medida, es poco menos que imposible entender la matriz de los antagonismos sociales que distinguen al modo de producción capitalista, y se asumen como meras anomalías, disfuncionalidades o aberraciones del neoliberalismo, el despojo o el ecocidio. A través de esa óptica, la denuncia sobre una nueva generación de cercamientos, despojo de bienes comunes, acaparamiento de tierras y extractivismo amerita un análisis a profundidad en el contexto del antagonismo social y la crisis del capital en tanto relación social, que subyace a la 
crisis de la forma de valor en el marco de la revolución científico-tecnológica en curso.

Con todo, en los trabajos más difundidos acerca de la actualidad de la acumulación originaria bajo la pauta de la desposesión se echa de menos la falta de consideración de la primacía de las relaciones sociales que subyacen a las dinámicas estructurales que han configurado históricamente al capitalismo, puesto que en su lugar se exalta la idea de que con la desposesión, el robo, el saqueo, se generan las condiciones necesarias para la apropiación privada de riqueza; no obstante, con esto se encubre el propósito correlativo de generar una masa de proletarios, el soporte social del modo de producción. Al recuperar el estudio de Marx, puede advertirse que su método de análisis no se reduce a denunciar el susodicho despojo sino que también advierte el significado histórico del proceso de proletarización y la consecuente espiral de capitalización que de ello se deriva.

\section{Rentismo}

En el siglo XXI, cuando se supone que campearía un capitalismo posmoderno, posindustrial, una sociedad del conocimiento, una utopía tecnocrática compartida por las previsiones del capitalismo prometeico donde campearía el general intellect y la ley del valor eventualmente perdería centralidad en el capitalismo para derrocar el trabajo forzado para dar paso al trabajo libre y creativo, según las leyes de la belleza (Marx, 2006). No obstante, el capitalismo del siglo XXI reedita las formas más bárbaras del despojo y sigue explotando en grado superlativo el trabajo inmediato, concreto, las cuales han sido una constante desde el siglo XIX hasta el presente, 
pero ahora se presentan con mayor crueldad. Esto se debe a que el capitalismo es rentista y explotador como nunca o como siempre lo ha sido.

Bienes naturales que no son producidos por el trabajo humano, no son mercancías, como el petróleo, minerales, agua potable y la tierra, existen en la naturaleza y para desgracia del capital no pueden ser producidos, aunque sí son tratados como mercancías, puesto que son muy lucrativos cuando se insertan en el mercado, pues alcanzan altas cotizaciones, sea por su relativa escasez o porque se especula con ellos. Entonces los capitales emprenden una competencia por apropiarse de esos bienes y ejercer un poder monopólico, para ello tienen que desplazar a las comunidades o pueblos que tienen usufructo de los espacios donde están alojados, y se valen del Estado, las leyes y violencia para despojarlos y apropiarse de esas demarcaciones, donde sentarán sus dominios y sustraerán la riqueza bruta del suelo o el subsuelo para mercantilizarla o transformarla. En ese cometido, las corporaciones se expanden en el tablero de la economía mundial, sobre todo en las regiones llamadas periféricas o dependientes, para repartirse los bienes de la naturaleza y aprovechar los reservorios de fuerza de trabajo barata, literalmente se trata de un nuevo reparto del mundo. En esa empresa se están disputando el control de las fuentes de ganancia extraordinaria derivadas de las rentas territoriales.

El capital rentista que se expande por el orbe para saciar su hambre de renta territorial, una ganancia extraordinaria, representa por ahora la expresión más dramática, más cruenta, de la crisis civilizatoria. La apuesta por la renta y la avanzada de la depredación están motivadas por el capitalismo de la crisis, un arrayador mecanismo rentista, especulador y parasitario que inca sus colmillos sobre el tejido social para succionar la savia de la vida, para rejuvenecer al capitalismo canalla. 
Lejos de una interpretación fisiócrata, donde la fuente de la riqueza deviene de la fertilidad de la tierra, o de la teoría neoclásica que parte de las relaciones de mercado y de los precios, en la teoría de la renta formulada por Marx (1999) queda claramente establecido que la renta no la produce la naturaleza sino la inversión de capital y la aplicación del trabajo humano sobre estos recursos. Elementos existentes en la naturaleza, no creados por la actividad humana — sea tierra, petróleo o mineral—, tan sólo por estar bajo tierra resguardados como un tesoro, no generan por sí mismos la renta, la teoría del valor desarrollada por Marx estipula que es el trabajo humano el creador de la riqueza expresada como un plusproducto, un plusvalor. Así, la renta de la tierra es una porción de plusvalor, el margen de sobreganancia que determinados capitales pueden extraer de la bolsa común de plusvalía que comparte el capital colectivo, en específico la multiplicidad de capitales que detentan un poder de monopolio sobre los bienes naturales sujetos a explotación, y entre más altas las cotizaciones por monopolio, escasez, patente o especulación, mayor será la ganancia extraordinaria. En el reparto del botín operan formas desiguales o inequitativas, dependiendo del poder de los capitales individuales, de los mecanismos de regulación estatales y de las formas de resistencia de las comunidades afectadas y de los trabajadores explotados.

En el capitalismo contemporáneo, donde se supone debería campear el trabajo liberado por las tecnociencias, el capital rentista está desbocado en busca de obtener grandes beneficios ejerciendo su poder de monopolios sobre recursos escasos, cercados o patentados. Pareciera ser una forma retrógrada o regresiva del capitalismo, pero es una de las formas insertas en la modernidad capitalista que conjuga la violencia, la acumulación y el rentismo. 
El capitalismo se expande de manera permanente mediante la violencia para conquistar territorios y sus bienes de aquellos ámbitos que aún no han sido subsumidos por la lógica de valorización. La generación y apropiación de nuevas fuentes de ganancia suscita una disputa por el excedente económico que se apropian los capitales que ejercen el monopolio y que es capitalizado bajo la forma de rentas en diversas ramas de la producción.

La prepotencia del capitalismo se verifica de una y mil formas, como sucede con la apropiación de los territorios y sus recursos, los derechos y sus instituciones, sin pedir permiso o con el respaldo de la fuerza legal y extralegal; sin embargo, ese embate está siendo resistido masivamente, no sólo en los ámbitos de la violencia que recuerda la acumulación originaria, esa forma crónica de violencia sin reposo, sino también en el ámbito político donde afloran movimientos, frentes electorales y gobiernos que pretenden contrarrestar el despojo secular con diversas estrategias y disímiles resultados.

\section{Explotación superlativa}

El sistema capitalista se funda y sostiene en una violencia económica diaria, cotidiana, concreta: la explotación del trabajo vivo, principalmente bajo la forma del trabajo asalariado, aunque también del trabajo no asalariado (campesino, doméstico, profesionistas libres, autoempleados, etcétera). Dicha violencia de tan evidente, pasa inadvertida, puesto que es encubierta por el marco legal, que la describe como una relación contractual entre iguales, entre personas libres.

Acrecentar persistentemente el plusvalor es el palmarés del capitalista, ya sea mediante la prolongación de la jornada de trabajo o mediante 
el incremento de la intensidad del trabajo (productividad); sin embargo, existe un tercer método que consiste en «la reducción del salario del obrero por debajo del valor de su fuerza de trabajo» (Marx, 1987a:381). Esto último parecería una anomalía del sistema capitalista o cuando mucho un rasgo temporal, puesto que teóricamente se supone que la fuerza de trabajo, siendo una mercancía, se paga de modo invariable por su valor, o sea, haciendo abstracción de los movimientos de oferta y demanda, en el mercado normalmente ocurre un intercambio de equivalentes, entonces se asume una ecuación de igualdad entre el valor y el precio, lo cual en términos laborales significa que existirá una relación de equivalencia entre el valor de la fuerza de trabajo y el salario devengado por el trabajador. Una relación de equilibrio que puede ser sometida a la baja o al alza de conformidad a la correlación de fuerzas entre capital y trabajo para pactar las condiciones de trabajo dentro de un grado de desarrollo de las fuerzas productivas y de la cultura que establece el valor de la fuerza de trabajo, es decir, las condiciones materiales y espirituales para su reproducción que se satisfacen vía salarial.

Desde la lógica del capital, y más desde una ética del capitalismo fundada en la laboriosidad, empeño de los individuos y la religiosidad (Weber, 2013), la idea de que el trabajo asalariado se pagaba por su valor (el valor de la fuerza de trabajo), en tanto intercambio de equivalente, no entraña robo alguno, pues a la vista de todos el contrato colectivo o individual establece condiciones de trabajo previas a su realización de común acuerdo, entre iguales. No obstante, cuando Marx (1988a) devela que en la relación entre capital y trabajo subyace una relación de explotación, en tanto el móvil es la sustracción de un plustrabajo que se realiza durante un plustiempo de trabajo en el que se crea el plusvalor, la aparente relación de igualdad, 
supuestamente justa, en realidad significa una relación desigual, injusta, por tratarse de la extracción de un excedente, un hurto sobre el trabajo vivo. Incluso, cuando se reconoce que el pago de la fuerza de trabajo se hace por debajo de su valor, se trata de un grado superlativo de explotación o de superexplotación, por lo que supone un robo directo acrecentado, que a todas luces transgrede el precepto de intercambio de equivalentes tutelado por la ética capitalistas y por los economistas convencionales.

Para contradecir a la teoría, o al menos para apuntalar un filón teórico que pudiera considerarse una anomalía sistémica o un rasgo secundario, el capitalismo realmente existente ha recurrido a un mecanismo que se supondría anómalo o provisional para convertirlo en un dispositivo permanente, una violencia económica que se ha inoculado en la vida cotidiana, que consiste en pagar deliberadamente la fuerza de trabajo por debajo de su valor. Esto constituye una flagrante violación a la ley del valor cuando se establece un precio por debajo de su valor, pero sólo se hace con una mercancía peculiar, la fuerza de trabajo (Marini, 1973). Dicho mecanismo no puede hacerse extensivo al resto de las mercancías, puesto que los capitales no podrían operar con déficit y tendrían que cambiar de rama de producción o desaparecer del mercado. Hipotéticamente, el retiro de inversiones en una rama redundaría en escasez del producto y los precios tenderían a subir y sobrepasarían su nivel de valor durante un tiempo, de modo que habría estímulos con el fin de retomar la producción de esa mercancía y ocasionaría ajustes de precios, etcétera. Las condiciones geopolíticas para que este mecanismo fuera implementado se dieron después de la Segunda Guerra Mundial y, especialmente, en las economías periféricas, donde predominan capitales con baja composición orgánica de capital, que no pueden afrontar la competencia y recurren a ese mecanismo con el objeto de compensar sus 
pérdidas. Así, la superxplotación del trabajo significa un desfalco del fondo de vida obrero para compensar la formación de plusvalor de capitales con menor capacidad de competencia en el mercado mundial.

La superexplotación del trabajo no es un sólo es un problema de grado en la explotación, de suyo un hurto del plustrabajo, del plusvalor creado, sino que además es un dispositivo aplicado por el capital de manera permanente para acrecentar la extracción de plusvalor y afrontar la competencia intercapitalista, sin importar que con ello se deteriore aceleradamente la calidad de vida de los trabajadores y la reproducción social en general. Si el despojo es un signo originario y permanente, la explotación superlativa del trabajo vivo se convierte también en una medida permanente. Entonces, puede afirmarse que, si el capitalismo clásico está fundado en la violencia económica de la explotación, el capitalismo subdesarrollado y dependiente, donde prevalecen el método de la superexplotación, se erige sobre una hiperviolencia económica, que es constituyente de una sociedad opresiva, desigual e insustentable. El problema no se resuelve eliminando el grado superlativo de explotación, pues persistirá el fundamento del capitalismo, la explotación, la extracción de plusvalía. Esto es, la solución no radica en suprimir el grado superlativo de la explotación para instaurar un régimen de acumulación basado en una explotación a secas, sino en la supresión de las relaciones de explotación. La superexplotación se funda, a su vez, en las relaciones de dominación entre países con distintos grados de desarrollo y la división internacional de trabajo que hace posible la transferencia de valor de unas regiones a otras; sin embargo, tampoco el hipotético equilibrio o complementariedad intrarregional resuelve el problema de la violencia económica, como lo podría hacer la creación de una economía fundada en otra forma de sociedad libertaria. 
La fuerza de trabajo, en el capitalismo, no es una mercancía como cualquier otra, de hecho, es la mercancía más importante, por cuanto es la única capaz de generar valor. No existen condiciones para que el pago de un salario (precio) por debajo de su valor redunde en el retiro de los trabajadores del mercado de trabajo y de la producción. Esta es una premisa básica del capitalismo, el trabajo forzoso, puesto que los obreros al ser despojados de sus medios de producción no cuentan con otra opción más que la de vender «libremente» su fuerza de trabajo al mejor postor, el empleador que lo reclute y lo someta al régimen de producción.

En cada periodo histórico y espacio se determina el valor de la fuerza de trabajo (Marx, 1849), por lo que resulta poco menos que imposible precisar con certeza una canasta de productos y servicios permanente que contenga los elementos mínimos para la reproducción social de los trabajadores. Interfieren además factores económicos como nivel de ingreso y bienes disponibles; y políticos, como la correlación de fuerzas entre trabajadores y empresarios, la existencia de trabajadores desempleados y las políticas estatales.

La depresión de los salarios por debajo de su valor repercute en la disminución de la calidad de vida y la precarización de la reproducción de los trabajadores y sus familias en un momento específico del desarrollo sociocultural. De forma directa, el pago de salarios bajos desvaloriza el valor de la fuerza de trabajo y deteriora la reproducción de los trabajadores con una caída en el nivel de vida en los ámbitos de alimentación, salud, vivienda, educación, calificación laboral, acceso a cultura, etcétera. Contribuye a ello la sobreoferta de trabajadores, un abundante ejército de desocupados en un contexto demográfico con población supernumeraria y una economía con sectores atrasados y desigualdades regionales, aunado al progresivo deterioro de formas de producción, como el campesinado, 
obligado a emigrar a las ciudades del propio país o a los países de mayor desarrollo relativo.

Algunos factores estructurales contribuyen a ese proceso: la existencia de estructuras demográficas con sobrepoblación relativa, las modificaciones de los patrones de consumo inducidos por la industria, la liberalización de mercados y la importación de alimentos — la dieta neoliberal (Otero, 2014)_y las condiciones de negociación entre sindicatos, patronal y el Estado.

Con todo, es posible advertir que la superexplotación es un síntoma de la crisis civilizatoria, de la degradación extrema de la condición humana directamente por el yugo del capital.

\section{Violencia estatal}

De acuerdo con Marx y Engels (2011:52): «El poder estatal moderno no es más que una junta administradora que gestiona los negocios comunes de toda la clase burguesa». El poder político de la oligarquía y el imperio imponen la fuerza del orden y el dinero. La república burguesa puede conducirse bajo las premisas de la democracia y el libre mercado encubriendo los conflictos y las contradicciones, pero a menudo degenera en la pulsión de muerte y el comportamiento suicida. En los secretos del poder, los arcana impèrri, más allá de la razón de Estado, subyace la violencia, la dominación irrestricta, para hacer posible la materialidad del desarrollo capitalista. 


\section{Contra los trabajadores}

El descenso del nivel general de vida de las clases trabajadoras, asalariadas y no asalariadas, depende de la correlación de fuerza entre el capital global y el trabajo social sujeto a explotación directa o indirecta, valga decir, al estado de la lucha de clases. Es una correlación desigual. De un lado, el poder del capital y el Estado, al unísono defienden el sistema capitalista basado en la explotación y sus mecanismos políticos de reproducción, en las últimas décadas sintetizadas por la ideología neoliberal y el programa económico de globalización. Del otro lado, el poder de los sectores explotados, la clase trabajadora, que tiende a fragmentarse en una multiplicidad de movimientos y organizaciones sin capacidad de coaligarse y unirse en torno a un propósito común, sintetizado en la frase «iProletarios de todos los países, uníos!» del Manifiesto del partido comunista (Marx y Engels, 2011:97), que apostaba por el internacionalismo obrero, la concientización y organización de las clases explotadas y la realización de una revolución generadora de una sociedad libertaria.

Luego de una fase ascendente del capitalismo mundial y de una cierta organización de los trabajadores que lograra alcanzar derechos laborales y un pacto social que moldeara al 1lamado «Estado social», con sus formas diferenciadas de Estado benefactor en la Europa desarrollada y Estado desarrollista en América Latina y otras regiones periféricas, desde la década de 1970 se emprende una embestida del Estado contra la clase trabajadora para despojarla de los derechos sociales y laborales, destruir el poder de los sindicatos, flexibilizar los mercados laborales, precarizar las condiciones de trabajo, desmantelar la red de protección social, despolitizar y derechizar a las clases populares. El proyecto de neoliberalización 
significó la concentración de poder y riqueza en manos de una élite social, encabezada por las grandes corporaciones multinacionales, la alta burocracia estatal y la tecnocracia gestora de los poderes ascendentes. En contraste, la proliferación del programa neoliberal repercutió en el derrocamiento del poder de clase de los trabajadores y el descenso consecuente de la calidad de vida de los trabajadores y la disminución salarial redunda en un incremento del plustiempo de trabajo, del plusvalor.

En los países subdesarrollados y dependientes, en particular América Latina, la coerción directa de los gobiernos autoritarios o dictaduras sirve para reprimir las diversas expresiones de poder popular representadas por partidos políticos, sindicatos, líderes e intelectuales y a su vez para desvalorizar la fuerza de trabajo e imponer un régimen económico que normalice el deterioro de las condiciones de vida hasta llegar a pagar la fuerza de trabajo por debajo de su valor en abono del incremento superlativo de la ganancia.

La desvalorización de la fuerza de trabajo puede realizarse con la implementación de diversas medidas coercitivas, incluso de un modo encubierto, como sucede, por ejemplo, con la inflación, es decir, el incremento de las tarifas y precios de bienes y servicios, medidas de ajuste que suelen ser justificadas por los gobernantes y tecnócratas como parte consustancial del libre juego de las fuerzas del mercado, una entidad abstracta que no tiene mano negra sino una mítica mano invisible. La política de inflación de precios tiene el cometido no declarado de redistribuir los ingresos mediante el abaratamiento del costo salarial y el aumento de los márgenes de ganancias; la fórmula consabida es aumentar los precios y contener los salarios. Esta situación se agrava con la prédica neoliberal de la «austeridad», el ajuste de salarios y la subida de precios, que además restringe el gasto social con el cual eventualmente puede subsanarse, en parte, la desvalorización salarial 
con diversos bienes y servicios públicos que coadyuvan a la reproducción social. El denominado «salario real», es decir, el salario nominal deflactado o su poder de compra, disminuye y se profundiza el efecto progresivo de la desvalorización de la fuerza de trabajo, una tendencia derivada de la correlación política de fuerzas desfavorable al mundo del trabajo que se justifica ideológicamente como producto natural de la economía de mercado.

\section{Estado de excepción permanente o el fascismo como sistema}

Acuñado por Carl Schmitt, el término Estado de excepción se refería a la suspensión del orden vigente en aras de una preservación del poder soberano que ejerce el «monopolio de la decisión última» (1968:151). Para la concepción liberal, la existencia de peligros internos o externos que ponen en predicamento el Estado de derecho concita a que el gobierno en turno - sea el presidente o el parlamento — aplique la ley y decrete el Estado de excepción, el Estado de sitio o la suspensión de garantías hasta en tanto no sea superada la situación de emergencia y se logre reestablecer el Estado de derecho. En contraste, el fascismo considera que el soberano, en quien radica el precepto de la soberanía, y no en el pueblo, es quien tiene la atribución de decidir el Estado de excepción (Schmitt, 2009). En la medida en que su poder precede al Estado de derecho y tiene la facultad de tomar decisiones por fuera del marco de derecho y entonces también puede suspender el Estado de excepción para restablecer el marco jurídico o imponer uno nuevo. El ejercicio de un poder discrecional semejante redunda en una dictadura constitucional que contraviene al Estado liberal.

Al criticar las concepciones liberal y fascista, Benjamin (1942) se refiere al Estado de excepción permanente: «La tradición de los oprimidos nos 
enseña que el <estado de excepción` en que ahora vivimos es en verdad la regla. El concepto de historia al que lleguemos debe resultar coherente con ello. Promover el verdadero estado de excepción se nos presentará entonces como tarea nuestra, lo que mejorará nuestra posición en la lucha contra el fascismo» (1942:679). Para Benjamin, el derecho es un producto, un orden impuesto por la violencia. Al respecto, establece una diferenciación entre una violencia constituyente fundada en el derecho y una violencia constituida que se mantiene y esgrime ante los enemigos. La violencia sobre los oprimidos define la existencia del estado de excepción permanente, pero el soberano no dispone de la capacidad para establecer el estado de excepción, pues de por sí ya es la regla. La crítica de Benjamin desplaza la discusión del ámbito del soberano y del derecho para situarlo en la historicidad donde la violencia juega un papel central. El orden establecido mediante la violencia de los vencedores sólo puede sostenerse por la violencia sobre los oprimidos que son sus enemigos. La liberación del hombre de la opresión requiere la supresión del Estado de excepción permanente y la creación de un estado de excepción verdadero a través de la violencia pura, la violencia revolucionaria, que va más allá del sistema jurídico.

Con el reconocimiento de que el Estado de excepción adquiere una condición permanente, se asume que el Estado de derecho ha sido violado en el terreno de los hechos y entonces los poderes fácticos instauran las condiciones de su régimen de dominación en la república burguesa. En términos conceptuales, el Estado de excepción permanente representa un oxímoron al conjugar en un mismo horizonte de significado lo originario con lo permanente, una excepcionalidad que se convierte en regla, una condición originaria que trasmuta en permanente. No obstante, da 
cuenta del carácter contradictorio, grotesco, del capitalismo, que encuentra en la emergencia del fascismo societal su obscena convivencialidad. En el capitalismo la violencia es fuerza originaria y permanente, y el estado de excepción es una fuerza instituyente originaria, que luego se estabiliza para adoptar la forma de un estado de derecho sin violencia aparente, que incluso pervive bajo e imperio de la ley y al cobijo de una normalidad democrática burguesa, aunque en realidad el Estado de excepción con violencia es una institución permanente dentro del capitalismo, donde la formación social se erige sobre un régimen de explotación y despojo. Se requiere, entonces, la instauración de otro estado de excepción que imponga un régimen social donde prevalezcan condiciones de existencia favorables a quienes están sujetos a la violencia capitalista. La dialéctica destituyente-constituyente del Estado de excepción asume diversas figuras, como el paso de una república burguesa a una república social.

\section{Actualidad de la política de excepción}

Desde el pensamiento neoconservador y la política neofascista, el Estado de excepción ha sido recuperado, tomando como pretexto el combate al terrorismo, la guerra contra las drogas, la política antiinmigrante, el nacionalismo refractario y el populismo de derechas. Un punto de inflexión fueron los atentados del 11 de septiembre de 2011, cuando el gobierno estadounidense decreta unilateralmente el Estado de excepción que desconoce el derecho internacional y parte el Estado de derecho a fin de enaltecer los intereses políticos conservadores y del capitalismo representados por el Estado estadounidense. Dicho proyecto abreva de la crítica schmittiana de la democracia y el Estado liberal. 
En contrapartida, desde el flanco crítico se retoma el concepto de Estado de excepción permanente de Benjamin (1943) y los conceptos de biopolítica y biopoder de Foucault (2000). En esta pauta, destacan autores como Hardt y Negri (2004) y Agamben (2004). Entre otras cosas, se advierte que otrora la guerra se circunscribía a una forma acotada de Estado de excepción, por lo que la forma de guerra civil tenía como referente la demarcación del Estado nación moderno, pero ahora se rompen los límites del marco jurídico de la soberanía y en consecuencia se amplía bajo la forma de Estado de excepción permanente:

Tan pronto como decae la limitación del espacio y el tiempo bélicos de la guerra en el conflicto limitado entre Estados soberanos, parece retornar la guerra como una marea que inunda todo el territorio social. El estado de excepción se ha convertido en permanente y generalizado; la excepción pasa a ser la norma e invade tanto las relaciones internacionales como el panorama interno» (Hardt y Negri, 2004:28).

En esa tesitura, la noción de biopoder es reconsiderada para analizar la condición subyacente al régimen de poder más allá del marco de la soberanía. Además de que la biopolítica se asume como el control político de la población mediante dispositivos tecnológicos de vigilancia y disciplina, un poder implementado sobre el conjunto de la población y la vida, es decir, los seres vivientes. Se ejerce un control sobre la población mediante la política de seguridad, sobre el territorio mediante la política de soberanía y del cuerpo a través de la disciplina.

Al influjo del neofascismo y sus políticas del miedo, represión y muerte, los estados adoptan la política de seguridad y el populismo punitivo como 
respuestas condescendientes para preservar el orden establecido: «La declaración del estado de excepción ha sido sustituida de forma progresiva por una generalización sin precedentes del paradigma de seguridad como técnica habitual de gobierno» (Agamben, 2004:27). ${ }^{1}$ O, como diría Marx, ante el conflicto, incluso bajo la presunción de la tutela jurídica, «entre derechos iguales decide la fuerza» (Marx, 1988a:282).

Agamben se refiera al homo sacer como la construcción social de «seres matables» dotados de una vida nuda, una vida que puede ser arrebatada y sacrificada sin que nadie responda por ella, sin mayores consecuencias, pero que están predestinadas a cumplir un papel en la política moderna. Actualmente, esa vida es encarnada por figuras convertidas en enemigos públicos o parias, como el terrorista o el delincuente pobre, que sólo son considerados en el orden vigente bajo la fórmula de la exclusión, lo cual incluye la posibilidad de matarlos sin que se incurra en una sanción jurídica o moral.

La humanidad prohijada por el capitalismo moderno se divide en clases sociales y en contradicciones sociales que convierte a algunas de estas clases como parte integrante de su dinamismo y a otras como sectores marginales, excluidos y redundantes, cuando no desechables. Una indeleble

${ }^{1}$ Para Agamben (2004:125-126), resulta indispensable mostrar que «la ficción que gobierna (...), lo que el poder contiene en su centro es el estado de excepción; pero no es éste esencialmente un espacio vacío, en el que una acción humana sin relación con el derecho tiene frente a sí una norma sin relación con la vida (...) que ha seguido funcionando casi sin interrupción desde la Primera Guerra Mundial, por la vía del fascismo y del nacionalismo hasta nuestros días. El estado de excepción ha llegado a alcanzar ahora su máximo despliegue planetario. El aspecto normativo del derecho puede ser así impunemente cancelado y contrariado por una violencia gubernamental que -ignorando en el exterior el derecho internacional y produciendo en el interior un estado de excepción permanente - pretende no obstante, seguir aplicando todavía el derecho». 
línea divisoria separa sectores sociales dotados de reconocimiento como humanos de otros que al ser prescindibles resultan no humanos o subhumanos, para los primeros los conflictos se negocian según los términos del derecho y para la franja de los no humanos con la violencia.

Ante la disyuntiva permanentemente abierta entre el capital o la vida, la moderna sociedad capitalista opta por la primera opción, de modo invariable. De ahí que la humanidad moderna que asume el sentido burgués de la vida tiene como contraparte una especie de subhumanidad, es decir, una parte abrumadora de la humanidad que es sacrificada como mero trabajo vivo para que un parte pujante de la humanidad florezca y se afirme como el sentido universal de la existencia. Autores como Fanon (2001), Duchrow y Hinkelammert (2003) y Freire (2005) exploraron ese juego de tensión dialéctica entre vida y muerte, o más precisamente de la humanidad negada por ser colonizados y oprimidos en beneficio de la parte civilizada de la humanidad que se afirma como ente universal de la cultura y la civilización.

Así pues, en la compleja sociedad capitalista actual la utopía tecnocrática prefigura una condición poshumana, los cyborg, seres de la ciencia ficción que cual Frankenstein posmodernos están siendo engendrados por las tecnociencias por medio de la síntesis de lo humano y lo tecnológico fundida en una antropotecnia que pretende superar los rasgos básicos de la humanidad bajo patrones tecnocráticos, que en el fin de los tiempos haría prescindible a la humanidad. En tanto que en la cotidianidad capitalista prevalece la humanidad inmersa en las dinámicas de reproducción de la lógica de valorización sobre un entramado civilizatorio dotado de formas del progreso y de conflictividad social que en todo momento plantea la disputa por los recursos, el excedente y el poder; empero, en los márgenes 
de la cartografía geoeconómica, incluso en la clandestinidad, perviven seres humanos considerados productos sociales desechables, sin derechos, no reconocidos como ciudadanos o catalogados como amenazas, reducidos a una vida nuda, los forman el trasfondo de la humanidad desgarrada, son los subhumanos.

Los motores propulsores del capitalismo del siglo XXI son la necropolítica y el gobierno privado indirecto (Mbembe, 2011). El nuevo espíritu del capitalismo está regido por una concepción de soberanía que no recae en los pueblos ni en las naciones sino en agentes económicos internacionales, poderes difusos y sin escrúpulos que asumen la potestad de decidir quién debe vivir y quién debe morir según los criterios de costo beneficio, los dictados del mercado. Las guerras de nuevo tipo son emprendimientos bélicos a cargo de grandes corporaciones privadas con la gestión de los Estados que ejercen un poder nomádico sobre un mundo sin fronteras, por lo que ya no intentan directamente conquistar territorio y someter a la población, sino que están interesados en apropiarse de los recursos estratégicos con el apoyo de nuevas tecnologías para obtener ganancias extraordinarias de corto plazo sin importar los costos humanos y ambientales implícitos. En tanto administración de la muerte, la necropolítica es la gestión de las poblaciones y de los territorios incluidos por los gestores del capital global que llegan a tasar a los seres humanos según los dictados del mercado, como si fuesen mercancías intercambiables o desechables, seres sacrificables y «matables». En el capitalismo canalla la vida humana y la naturaleza pierden su significado y asumen la figura de una simple moneda de cambio.

En el capitalismo contemporáneo, engreído por su programa de globalización, libre mercado, derechos humanos y democracia, pero a la vez 
deslegitimado por la irrupción de una crisis civilizatoria y el descreimiento generalizado de sus fundamentos, el concepto de Estado de excepción cobra palpitante actualidad. Aunque se redefine al calor de la preponderancia de Estados Unidos, la única superpotencia en el sistema mundial, ahora en crisis, que asume las mayores notas de excepcionalidad.

La «excepción americana», donde lo americano no se asume como un rasgo continental sino meramente estadounidense, además de que pretende separarse de otros imperios europeos, encubre el papel imperialista de Estados Unidos, articulado por la Doctrina Monroe desde 1823 y el expansionismo hacia el Pacífico y el Caribe en los 1940 y 1950, el intercambio, la inversión y el establecimiento de bases militares y la anexión de territorios en otros continentes (Sadowski-Smith, 2009); se refiere a que la superpotencia capitalista impone las normas internacionales y los programas económicos de donde emanan las principales directrices financieras y políticas. En esa inteligencia, vigila escrupulosamente que se cumplan sus determinaciones, pero no las obedece ni respeta. La afirmación de la soberanía de Estados Unidos no es republicana sino extraterritorial, imperialista para mejores señas, y se hace valer por la vía militar, financiera, comercial y cultural (Petras y Veltmeyer, 2006). El imperialismo ejerce una soberanía supranacional y difunde la forma de Estado de excepción permanente en diversas regiones del planeta como una política perversa de gobernabilidad tutelada por el imperio y asumida por las oligarquías nacionales.

La idea de que la soberanía de los Estados nación es sustituida por la soberanía supranacional que asume el control de la excepción permanente a escala global, donde los conceptos de soberanía y excepción se presentan paralelamente, es un planteamiento posmoderno donde es posible la existencia del imperio sin imperialismo (Hardt y Negri, 2002). Aun así, el 
imperio con imperialismo (Petras y Veltmeyer, 2006; Boron, 2004) continúa siendo un precepto analítico de la teoría crítica que explica el sistema capitalista mundial en pauta histórica y con énfasis en la dominación de los poderes estatales centrales sobre los estados periféricos; de ahí derivan formas de explotación en el mercado mundial de las economías centrales sobre las periféricas, como preámbulo para descifrar los capitalismos subdesarrollados y dependientes (Dussel, 2014), concretamente en las regiones poscoloniales, en las que se arraigan de manera particular los regímenes de Estado de excepción.

\section{Crimen perfecto}

En el plano individual, cuando una persona asesina premeditadamente a otra, se trata de un homicidio. En la comisión de este crimen existen diversas razones: pleito, robo, venganza, acto pasional. Pero el crimen social se remite a las raíces de la violencia estructural. Como lo planea Engels (1845), en la moderna sociedad capitalista se ensaya reiteradamente la muerte lenta y prematura de las clases trabajadoras. Cotidianamente, millones de personas en el mundo están supeditadas a sobrevivir en condiciones deplorables. Dentro de la normalidad de la reproducción social mediada por el poder del dinero, grandes parcelas de la humanidad subsisten con penurias, sean o no asalariadas. A diferencia del individual, el crimen social es tolerado, tanto porque está muy bien disimulado, nadie puede defenderse por sí mismo, como porque está inserto en la lógica de reproducción del sistema. En apariencia, no se comete crimen alguno; nadie ha atestiguado asesinato alguno. El capitalismo es el crimen perfecto. 
La espiral de violencia dentro de una fase avanzada del capitalismo, ahora en fase de decadencia, el modelo neoliberal se desboca por la instrumentalización de la violencia para orquestar el despojo y la acumulación, incluso recurre a la militarización y tácticas contrainsurgentes para disolver las protestas sociales y los movimientos antisistémicos. En específico, la entrada en funciones del capital criminal asociado a la llamada "guerra contra el narco», derivado de la doctrina de seguridad estadounidense, aflora como una especie de acumulación originaria permanente a cargo de un complejo empresarial-político-militar que conjuga actividades ilícitas y lícitas en torno al mercado de drogas y una gran cantidad de delitos asociados. La expropiación violenta de grupos criminales pretende apropiarse de tierras de campesinos y medios de producción con la intención de reconvertirlas en tierras clandestinas de cultivo de amapola y mariguana a fin de instalar infraestructura y equipamiento para esas actividades como laboratorios, bodegas y pistas de aterrizaje. Además, con la «liberación» de fuerza de trabajo se crea una reserva laboral que serán reclutados o sometidos a trabajo forzoso en la agricultura de exportación de enervantes, los cuales serán jornaleros, transportistas, que serán sobreexplotados y sobreexpuestos a la violencia policiaca, militar y judicial, que dirige sus fuerzas de detención, tortura y violación, asesinato, desaparición, juicio y encarcelamiento contra los eslabones más bajos y muy a menudo no violentos de las organizaciones.

El campo arruinado y los cinturones de miseria de las ciudades suelen ser los espacios donde se reclutan jóvenes y niños para que cumplan funciones degradantes como vigilantes, pistoleros y vendedores para el capital criminal y otras actividades insertas en las filas bajas de la diversificada estructura ocupacional de la economía ilegal. Paradójicamente, este sector 
se ha consolidado como uno de los principales empleadores de la economía mexicana y uno de las escasas opciones de supervivencia para el lumpenproletariado, ${ }^{2}$ el desbordante ejército de marginales que engendra el capitalismo neoliberal, pero dentro de un esquema de hiperviolencia que puede derivar en una muerte prematura, o bien ocasionar muertes en el entorno social.

El dispositivo de la violencia es una fuerza consustancial al despliegue y expansión del capital criminal que se activa no sólo para ocupar territorios, demarcar campos de cultivo, zonas de procesamiento y rutas de distribución, sino que también aflora en la forma peculiar de competencia que despliegan entre los grupos criminales que a nivel territorial se confrontan continuamente con el propósito de ejercer el control efectivo de los circuitos mercantiles, disputar la hegemonía en las llamadas plazas o centros operativos, además de resguardar las rutas de trasiego y los sitios de venta. En adición, se generarán confrontaciones para ganarse el privilegio de tejer redes de complicidad con agentes estatales que garantizan la fluidez de las transacciones ilegales y aseguran la impunidad de los jefes y mandos de las organizaciones. Por si fuera poco, se ejerce el terror para propagarlo entre la sociedad a fin de establecer un dominio informal y control territorial, junto con el silenciamiento de las voces críticas, periodistas, defensores de derechos humanos y familiares de víctimas.

${ }^{2}$ Según Marx: «Se organizó al lumpemproletariado de París en secciones secretas (...) junto a roués arruinados, con equívocos medios de vida y de equivoca procedencia, junto a vástagos degenerados y aventureros de la burguesía, vagabundos, licenciados de tropa, licenciados de presidio, huidos de galeras, timadores, saltimbanquis, lazzaroni, carteristas y rateros, jugadores, alcahuetes, dueños de burdeles, mozos de cuerda, escritorzuelos, organilleros, traperos, afiladores, caldereros, mendigos; en una palabra, toda esa masa informe, difusa y errante que los franceses llaman la bohème» (1988b:87). 
La producción y venta de drogas no es la única actividad del capital criminal, existe una gran diversidad de actividades que involucran al crimen organizado con agentes de la maquinaria estatal y empresarios. Marx (2008) ironiza sobre el papel de la criminalidad en la expansión de la riqueza nacional, puesto que los delitos producen el derecho, los jueces, la policía y a los investigadores del tema; aparte de que diversifica la división social del trabajo, crea nuevas necesidades y sus correspondientes satisfactores; descarga al mercado laboral al absorber a una parte de la sobrepoblación relativa, en funciones tanto delincuenciales como de lucha contra la delincuencia, y estimula el desarrollo de la productividad con la creación de nuevas mercancías y dispositivos de combate a la delincuencia.

El capital criminal y sus diversas instancias ilegales y legales, abiertas y encubiertas, emplean una diversidad de métodos que actualizan los dispositivos y propósitos registrados en la forma histórica de la acumulación originaria. Este tipo de capital se abre paso a sangre y fuego; impone su determinación con la espectacularidad de la prepotencia: comunidades rurales indígenas y campesinas son desplazadas por la fuerza, los territorios y la biodiversidad son despojados de los pueblos, los líderes y colectivos en resistencia sufren represión y asesinatos, los dirigentes de movimientos populares son apresados y sometidos a tortura, los bienes naturales son saqueados, las familias despojadas son supeditadas a regímenes de trabajo basados en la explotación superlativa y en muchos casos se imponen formas de esclavismo moderno y explotación infantil, los pequeños productores son sometidos al cobro de impuestos, pueblos enteros son asolados por la paramilitarización y grupos criminales y el conjunto de la sociedad cae presa de tácticas de disciplinamiento social mediante la proliferación del miedo y el terror, el castigo ejemplar y el populismo punitivo. 
Esta violencia significa la imposición de un Estado de excepción no declarado y la política del terror, la necropolítica, como dispositivos violentos que posibilitan a las organizaciones del capital criminal la persistencia de una economía de guerra criminal que garantiza los flujos de dinero negro, manchado de sangre, que enarbola uno de los negocios más rentables del capitalismo decadente (Calveiro, 2010; Altvater y Mahnkopf, 2008). La violencia del capital criminal representa una potencia económica, a la manera de la acumulación originaria, que impone las condiciones de posibilidad del capitalismo rentista y criminal. La violencia estatal se desdobla en un Estado mafioso coludido con el capital criminal y las fuerzas de paraestatales delincuenciales que actúan en los dominios territoriales donde se articulan las bases operativas de la economía criminal (Fazio, 2016).

Cuando una economía nacional encuentra en la venta de drogas y otras mercancías emanadas de la criminalidad una de sus principales fuentes de divisas, como sucede en el capitalismo neoliberal mexicano, estamos hablando de una economía de guerra criminal, un estado decadente del capitalismo.

\section{Cierre}

En la crítica de la economía política se develan varias pistas para analizar la actualidad del capitalismo signada por una hiperviolencia, una violencia desbordada con múltiples manifestaciones. El capital es el crimen organizado y la violencia del capital obedece a la pulsión acumulativa inmanente al capital: se expresa desde la violencia diaria, invisible, de la explotación del trabajo que da cuerpo y figura a la economía, la reedición de los métodos 
de acumulación originaria con el despojo de bienes comunes y nacionales y la formación permanente de un ejército de marginados conducidos hacia la migración forzosa, al trabajo formal desprotegido o al trabajo en la criminalidad.

El proceso vertebrador de la sociedad moderna, la acumulación de capital, está compenetrado e insuflado por la violencia, que no sólo hace acto de presencia como mecanismo fundacional sino como fuerza motriz del desarrollo capitalista. El despliegue de la violencia tiene su asidero permanente en el ámbito económico para perpetuar la explotación y expandir los dominios territoriales del capital, una violencia estructural sin solución de continuidad, que se complementa con la violencia política que no ceja de conferirle grado de normalidad a lo perentorio con la irrupción del Estado de excepción permanente, es decir, la violación al estado de derecho. Se trata, entonces, de una violencia originara y excepcional, pero también progresiva y permanente.

No en balde el capitalismo significa un sistema que continuamente está violando sus propias normas, trasgrediendo sus ilusorios códigos éticos y fundamentos civilizatorios. Por lo mismo, la conflictividad social se asoma una y otra vez. Frente a la violencia sistemática, la resistencia social asume un carácter renovado, cuando no una expansión global, que pasa de la mera posición defensiva, a la ofensiva política, en oleadas, flujos y contraflujos. Esta violencia «divina», en el sentido de Benjamin (1977), nos remite a una violencia de carácter ético y político por parte de quienes se ven compelidos a sobrepasar el orden establecido y eventualmente superar el fatalismo histórico. En distintos lugares, frente a diversas problemáticas, emergen grupos, organizaciones y formas de poder popular que dicen no aceptar este mundo capitalista violento refrendado por su Estado 
de excepción permanente y su acumulación originaria permanente para contraponer una violencia divina, trasgresora y revolucionaria.

La contracara del capitalismo tecnocientífico, financiarista, consumista y globalizado es el capitalismo rentista y predador que surca los territorios mediante el despojo y la superexplotación. Desde esta configuración abismal se advierte su talante violento, incluso su pulsión de muerte, hasta tocar notas suicidas. No podría ser de otra forma si no se admite con serenidad que el aumento inconmensurable de las ganancias extraordinarias de corto plazo, que seducen a los capitalistas contemporáneos, se inflan cuando se configura un régimen de escasez, especulación, hiperviolencia y muerte. En la trama del capitalismo donde algunos quieren ver espectacularidad, ligereza y liquidez, se teje a contraluz la crisis de la modernidad capitalista: el hambre, la pobreza, el ecocidio, etcétera. No es un apocalipsis teologal sino la evidencia de que la escasez de recursos, la pobreza humana, son proporcionales a la riqueza del capital rentista. No en vano, las catástrofes también son una ventana de oportunidad para los grandes negocios, y el fin del mundo es el negocio por excelencia. No se trata de un atavismo moral o de una lectura hipocondriaca sino de una interpretación del devenir del capital, del gran dinero que asume un protagonismo impersonal y que hará cualquier cosa, por más irracional que nos parezca, para incrementar las ganancias, así sea aumentar la escasez y el sufrimiento humano. El capitalismo nos está empujando hacia el cataclismo. No es el antropoceno sino el capitaloceno. 


\section{Referencias}

Agamben, Giorgio (2004), Estado de Excepción. Homo sacer II, 1, Valencia, Pre-textos.

Altvater, Elmer y Mahnkopf, Birgit (2008), La globalización de las inseguridades.

Trabajo en negro, dinero sucio y política informal, Buenos Aires, Paidós.

Amin, Samir (1985), La acumulación a escala mundial. Crítica de la teoría del subdesarrollo, México, Siglo XXI.

Arendt, Hannah (1998), Los orígenes del totalitarismo, Madrid, Taurus (135)

Bartra, Armando (2016), Hacia un marxismo mundano. La clave está en los bordes, México, Ítaca.

Bartra, Roger (1999), «Campesinado y poder político en México», en Bartra, Roger et al., Caciquismo y poder político en el México rural, México, Siglo XXI.

Benjamin, Walter (1942), «Teorías sobre la historia y otros fragmentos», en http:// www.bolivare.unam.mx/traducciones/Benjamin,\%20Tesis\%20sobre\%20 la\%20historia.pdf (1977), Para una crítica de la violencia, México, Premià.

Boron, Atilio (2004), Imperio \& imperialismo. Una lectura crítica de Michael Hardt y Antonio Negri, Buenos Aires, CLACSO.

Bujarin, Nicolai (1971), El imperialismo y la economía mundial, Córdoba, Pasado y Presente.

Calveiro, Pilar (2010), Violencias de Estado. La guerra antiterrorrista y la guerra contra el crimen como medios de control global, Buenos Aires, Siglo XXI.

Dussel, Enrique (2014), 16 tesis de economía política. Interpretación filosófica, México, Siglo XXI.

Duchrow, Ulrich y Hinkelammert, Franz J. (2003), La vida o el capital. Alternativas a la dictadura global de la propiedad, San José, DEI. 


\section{CAPITALISMO DEL FIN DE LOS TIEMPOS}

Engels, Friedrich (1845), La situación de la clase obrera en Inglaterra, en https:// www.marxists.org/espanol/m-e/1840s/situacion/situacion.doc

Fanon, Frantz (2001), Los condenados de la Tierra, México, Fondo de Cultura Económica.

Fazio, Carlos (2016), Estado de emergencia. De la guerra de Calderón a la guerra de Peña Nieto, México, Grijalbo.

Foucault, Michel (2000), Defender la sociedad, Curso en el Collàge de France (1975-1976), Buenos Aires, Fondo de Cultura Económica.

Freire, Paulo (2005), Pedagogía del oprimido, México, Siglo XXI.

Galafassi, Guido (2016), «Entre la acumulación primitiva y la reproducción ampliada. Una reactualización del debate y su correlación con la explicación de los conflictos sociales en América Latina», Política, 54(2).

Galeano, Eduardo (1971), Las venas abiertas de América Latina, México, Siglo XXI.

Hardt Michael y Antonio Negri (2002), Imperio, Barcelona, Paidós. (2004), Multitud. Guerra y democracia en la era del Imperio, México,

Debate.

Harvey, David (2003), El nuevo imperialismo, Madrid, Akal. (2014), Guía de El Capital de Marx. Libro primero, Madrid, Akal.

Hilferding, Rudolf (1963), El capital financiero, Madrid, Tecnos.

Hobson, John (1981), Estudio del imperialismo, Madrid, Alianza Editorial. Jameson, Fredric (2000), Las semillas del tiempo, Madrid, Trotta.

Lenin, N. (1973), El imperialismo fase superior del capitalismo, Buenos Aires, Cartago.

Luxemburgo, Rosa (1967), La acumulación de capital, México, Grijalbo. Marini, Ruy Mauro (1973), Dialéctica de la dependencia, México, Era. 


\section{Humberto Márquez Covarrubias}

Márquez, Humberto (2015), «Urdimbres de la crisis del capitalismo: proceso histórico y colapso civilizatorio», Estudios Críticos del Desarrollo, 7(12).

Marx, Karl (1849), «Trabajo asalariado y capital», en https://www.marxists.org/ espanol/m-e/1840s/49-trab2.htm

(1982a), El capital. Crítica de la economía política, tomo I, vol. 3, México, Siglo XXI.

(1982b), Elementos fundamentales para la crítica de la economía política (Grundrisse) 1857-1858, tomo I, México, Siglo XXI.

(1987a), El capital. Crítica de la economía política, tomo I, vol. 2, México, Siglo XXI.

(1987b), El capital. Crítica de la economía política, tomo III, vol. 6, México, Siglo XXI.

(1988a), El capital. Crítica de la economía política, tomo I, vol. 1, México,

Siglo XXI.

(1988b), El dieciocho brumario de Luis Bonaparte, México, Grijalbo.

(1999), El capital, Crítica de la economía política, tomo III, vol. 8, México,

Siglo XXI.

(2006), Elementos fundamentales para la crítica de la economía política

(Grundrisse) 1857-1858, tomo II, México, Siglo XXI.

_ (2007), Los debates de la Dieta Renana, Barcelona, Gedisa.

(2008), Elogio del crimen, Madrid, Sequitur.

Marx, Karl y Engels, Friedrich (2011), Manifiesto del partido comunista, Madrid, Alianza Editorial.

Mbembe, Achille (2011), Necropolítica, Barcelona, Melusina.

Nicolaus, Martin (1982), «El Marx desconocido», en Karl Marx Elementos fundamentales para la crítica de la economía política (Grundrisse) 1857-1858, México, Siglo XXI. 
Otero, Gerardo (coord.) (2014), La dieta neoliberal. Globalización y biotecnología agrícola en las Américas, México, Miguel Ángel Porrúa.

Petras, James y Veltmeyer, Henry (2006), Imperio con imperialismo. La dinámica globalizante del capitalismo neoliberal, México, Siglo XXI.

Sadowski-Smith, Claudia (2009), «Posnacioanlismo», en Mónica Szurmuk y Robert Irwin Mckee (coords.), Diccionario de estudios culturales latinoamericanos, México, Siglo XXI.

Schmitt, Carl (1986), La dictadura. Desde los comienzos del pensamiento moderno de la soberanía hasta la lucha de clases proletaria, Madrid, Revista de Occidente.

Schmitt, Carl (2009), Teología politica, Madrid, Trotta.

Wallerstein, Immanuel, Collins, Randall, Mann, Michael, Derluguian, Georgi y Calhoun, Craig (2015), ¿Tiene futuro el capitalismo?, México, Siglo XXI.

Weber, Max (2013), La ética protestante y el espiritu del capitalismo, Madrid, Akal.

Žižek, Slavoj (2014), Problemas en el paraíso. Del fin de la historia al fin del capitalismo, Barcelona, Anagrama. 